\title{
Continental molluses of the fossil site Sandelzhausen (Miocene; Upper Freshwater Molasse from Bavaria) and their value for palaeoecological assessment
}

\author{
Markus Moser · Hans-Jörg Niederhöfer • \\ Gerhard Falkner
}

Received: 12 July 2007/ Accepted: 4 August 2008/Published online: 17 February 2009

(C) Springer-Verlag 2009

\begin{abstract}
The continental mollusc fauna of Sandelzhausen (Southern Germany, Early/Middle Miocene, MN5) is presented and shown to consist of 66 snail and 3 bivalve taxa. Previous ecological interpretations were partly based on poorly preserved material and are shown to be erroneous. Within a series of quantitative samples, ecologically four mollusc communities can be distinguished (two each for terrestrial and freshwater molluscs), highly indicative of ecological conditions and changes in the landscape surrounding the fossil site as well as the locality itself. Open scrub-lands with temporary waters, as indicated by forms such as Granaria and the dominance of lymnaeids, are steadily replaced with damp forests with abundant litter and rotting wood surrounding a perennial lake with small tributaries. These more favorable conditions are indicated by an overall increase of mollusc diversity, rising abundance of planorbids, and presence of restricted forms such as Drepanotrema (intolerant to droughts) as well as certain forest dwellers such as Gastrocopta and hygromiids. Molluscs are highly sensitive to environmental changes, which is reflected in the fossil record of Sandelzhausen.
\end{abstract}

Keywords Sandelzhausen · Germany · Miocene · Continental Mollusca · Gastropoda · Planorbidae .

\footnotetext{
M. Moser ( $₫)$ Richard-Wagner-Str. 10, 80333 Munich, Germany

e-mail: dml_moser@web.de

H.-J. Niederhöfer · G. Falkner

Staatliches Museum für Naturkunde Stuttgart,

Museum am Löwentor, Rosenstein 1,

70191 Stuttgart, Germany
}

Bayerische Staatssammlung für Paläontologie und Geologie,
Lymnaeidae $\cdot$ Granaria $\cdot$ Drepanotrema $\cdot$ Gastrocopta . Palaeoecology $\cdot$ Palaeoenvironment

Kurzfassung Die Binnenmollusken-Fauna von Sandelzhausen (Süddeutschland, Unter/Mittelmiozän, MN5) bestehend aus 66 Schnecken-und 3 Muschel-taxa wird vorgestellt. Frühere ökologische Interpretationen basierten teilweise auf schlecht erhaltenem Material und die resultierenden Irrtümer werden aufgezeigt. Innerhalb einer Serie von quantitativen Proben können vier Molluskengemeinschaften unterschieden werden (je zwei für Landschnecken und für Süßwassermollusken), die hervorragende Indikatoren sind für die ökologischen Bedingungen und Veränderungen sowohl in der umgebenden Landschaft der Fossillagerstätte als auch der Fundstelle selbst. Offene Buschlandschaften mit Temporärgewässern - angezeigt von Formen wie Granaria und die Dominanz der Lymnaeiden - werden allmählich ersetzt durch feuchte Wälder mit Laubstreu und verottendem Holz in der direkten Umgebung eines ganzjährig wasserführenden Sees mit kleineren Zuläufen. Diese günstigeren Bedingungen zeigen sich in einer höheren Gesamtdiversität der Molluskenfauna, der größeren Häufigkeit von Planorbiden, der Gegenwart anspruchsvoller Formen wie trockenheits-unverträgliche Drepanotrema und durch bestimmte Waldbewohner wie Gastrocopta und Hygromiiden. Mollusken reagieren hochsensitiv auf Umweltveränderungen und dies wird im Fossilbericht von Sandelzhausen reflektiert.

Schlüsselwörter Sandelzhausen - Deutschland · Miozän · Binnenmollusken · Gastropoda · Planorbidae · Lymnaeidae · Granaria - Drepanotrema · Gastrocopta . Paläoökologie · Paläoumwelt 


\section{Introduction}

Snail shell fragments from Sandelzhausen (MN5, Lower/ Middle Miocene) were first noticed by Prof. Richard Dehm in 1959. During one of the occasional weekend field trips with his family he went on searching for potential fossil mammal sites in the Molasse hills of Upper and Lower Bavaria (Fahlbusch 1974). The site he discovered has been exploited since then mainly for its vertebrate contents. A notable exception was the systematic collection of molluscs carried out by Horst Gall and colleagues during the first excavation period (1969-1975). Preliminary results were published after the first season of systematic excavations and recorded 16 species and ten families of Gastropoda and two species of Bivalvia (Gall, in Fahlbusch and Gall 1970). A more extensive description of the mollusc fauna based on more comprehensive material was presented by Gall (1972), who listed 49 land and freshwater species of gastropods and two bivalve species. Gall (1972: 4) emphasized the poor state of preservation of this material consisting of several hundreds of specimens. However, his taxonomy was mostly resolved even to subspecies level and relied heavily on the known mollusc faunas of the Suebian "Silvanaschichten" (Wenz 1920, 1924) and other southern German localities as well as the rich locality of Sansan (France), following the nomenclature used by Wenz (1923-1930, 1938-1944) and Zilch (1959-1960). However, it must be emphasized that the Sandelzhausen fauna then thought to be equivalent with Sansan and Steinheim since then has been found to significantly predate these other localities (Moser et al. 2009 this volume). Therefore, the taxa listed for Sandelzhausen as well as for most other localities should be revised in light of the fact that nonmarine gastropods have been shown to evolve rapidly and frequently exhibit convergent morphologies (e.g., Mensink et al. 1984; Willmann 1988).

In a second work devoted entirely to the gastropods of Sandelzhausen, Gall (1973) specifically addressed the five types of preservation observed among gastropods in Sandelzhausen: complete shells, natural marl casts, compressed shells, coquina, and concretionary blown-up shells (see Fig. 1 and Figs. 2, 3, 4, 5, 6, 7, 8, 9 for examples). [We translate the German expression "aufgebläht" used by Gall (1973) literally as "blown up," though noting that the English expression is used for rapid explosive processes rather than a slow expansion within a geological time frame. However, given that the snail shells were burst into pieces, we find "blown up" a more figurative term than "expanded," which is more suitable for elastic or plastic deformations]. As these preservation types are not distributed randomly within the section, Gall (1973) hypothesized that the concretionary blown-up shells were embedded still with their soft body and that the decomposition of the latter
Fig. 1 Lithology and preservation types. a Test section of 1966 (photography courtesy of Volker Fahlbusch) with stratigraphic nomenclature indicated. b Radix sp., leg. Alexander Heyng 1997. c Accumulation of Planorbidae, layer B, 1995. d Shell concentration in the "coal layer" (C2) in the Eastern part of the excavation site, 1996. e Typical section in Sandelzhausen, located at PQ 10-F. The lithological column does not show organic components (bones, shell beds) except for the "coal layer" (shaded). Carbonate nodules comprise a major part of the sediment volume in layers A to B2 (not shown proportionally). The frequency of carbonate nodules is basically the same as the frequency of blown-up macrogastropods. The frequency of shell beds peaks in layers $\mathrm{C} 1-3$, when sedimentation rates were low, and follows roughly the frequency of macrogastropods elsewhere. Stratigraphic positions of the screenwashed samples I-IX from PQ 10-G used in this work are indicated. f Percentage frequency of the four macrogastropod preservation types as distinguished by Gall (1973, Fig. 1)

yielded the chemical milieu for the growth of calcareous nodules: a process similar to the development of geods in marine and limnic sediments. Gall (1973) therefore concluded that terrestrial snails with predominantly "normal" preservation (i.e., not blown up) were allochthonous elements washed into the Sandelzhausen pond, while predominantly blown-up species would indicate an autochthonous faunal element, potentially buried quickly with their soft tissue. Gall thus derived a statistically based palaeohabitat evaluation of the gastropod fauna, inferring very different habitats for even closely related species on the basis of their different preservation mode frequencies.

During the later excavation period (1994-2001), mollusc sampling efforts were reduced to occasional salvages of few specimens (e.g., Fig. 1b). However, field observations 1996-1998 raised doubts regarding an organogenic development of the concretions and the dependent ecological interpretations made by Gall (1973). Fahlbusch (1974: 461) already suspected a diagenetic origin for the nodules and recently palaeopedogenesis became substantially documented (Moser 2000; Schmidt 2002). Extensive investigations of the palaeosoils of Sandelzhausen by Schmidt (2002) have proved the pedogenetic origin of the carbonates and other features. Carbonate pedogenesis is also known from Miocene alluvial and lacustrine deposits elsewhere (e.g., Retallack 2001; Bustillo and Alonso-Zarza 2007).

During the Sandelzhausen Symposium 2005 in Mainburg (Kowalke 2005; Moser 2005), further discussions regarding the palaecology of the fauna found the previous ecological and taxonomical evaluation of the mollusc fauna by Gall $(1972,1973)$ to be in urgent need of revision.

In the present contribution the entire mollusc record derived from Sandelzhausen has been considered for the first time. However, detailed taxonomical revision and stratigraphical as well as biogeographical comparisons will be presented elsewhere and are beyond the scope of this work. The present work treats ecological questions, thus 


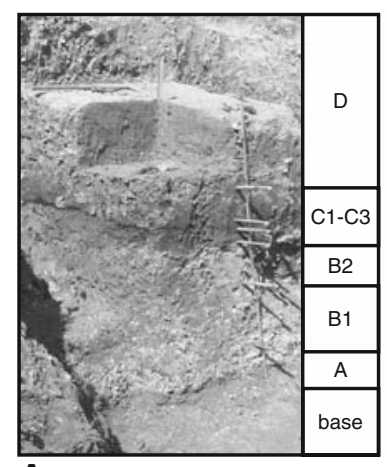

A

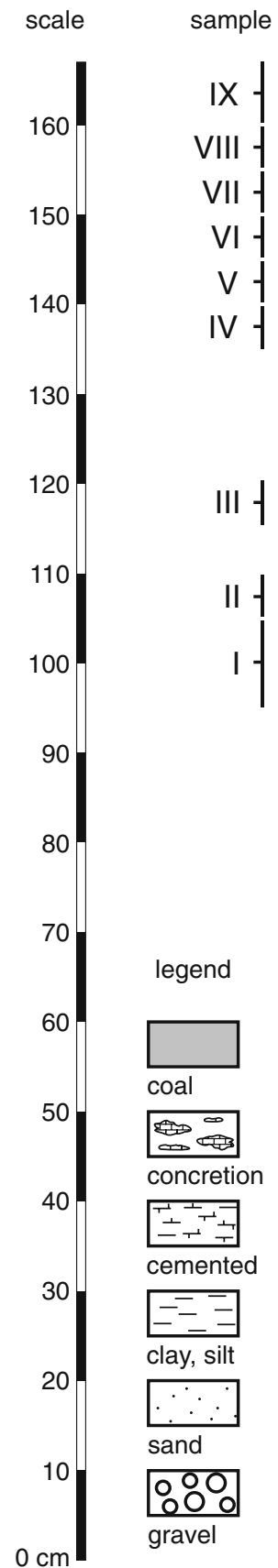

E

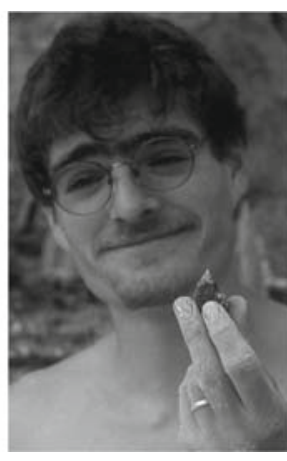

B

litholog

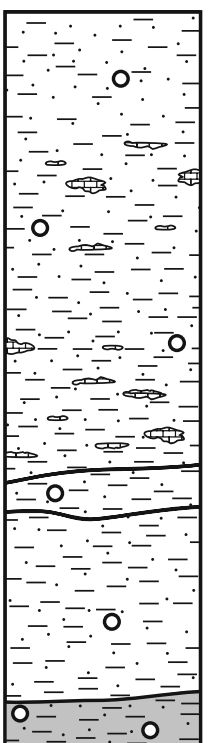

$0=0$

$0=0$
$00=0$
0.000

$0-0.90$

$00=0$

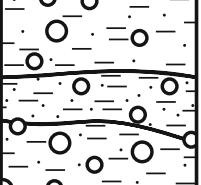

$5=0-0=0-$

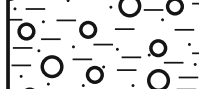

$0+0.0=$

$0.0-0$

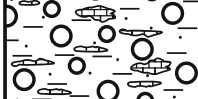

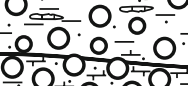

10.0

10:0

5.:-0.

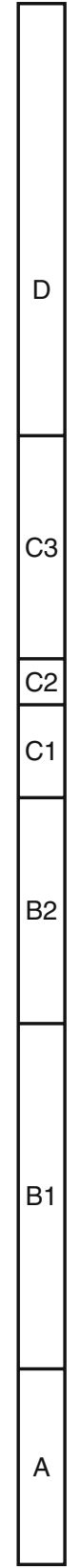

B2

\begin{tabular}{l} 
D \\
\hline C3
\end{tabular}

C2

C1

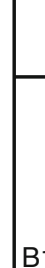

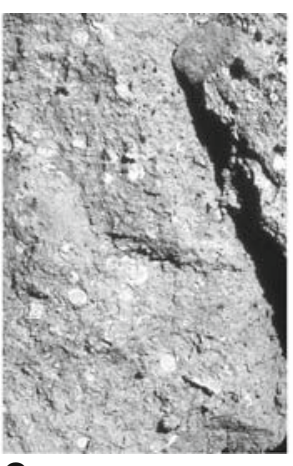

C

preservation type frequency distribution

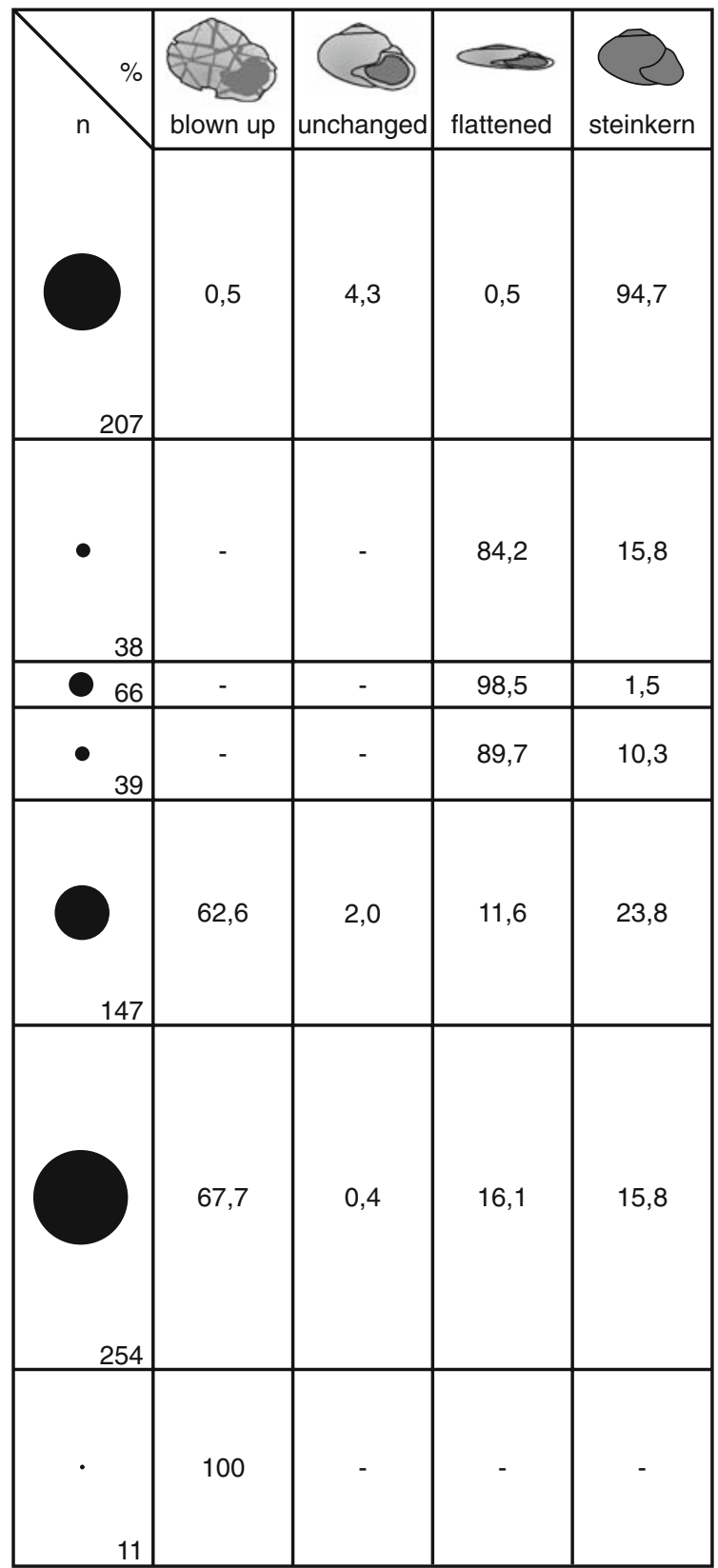

$\mathbf{F}$

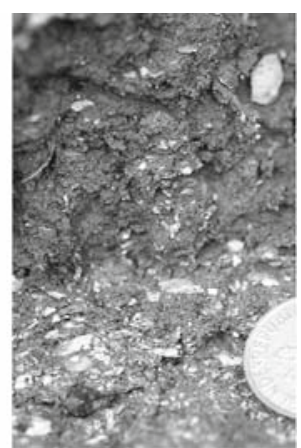

D 


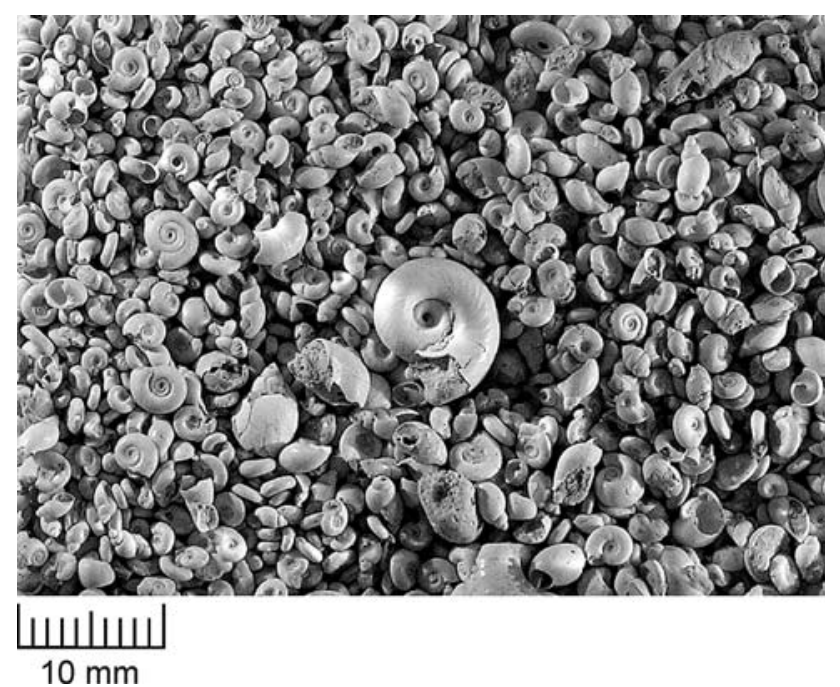

Fig. 2 Screen-washed sample. Screen-washed sample of Sandelzhausen gastropods from location PQ 10-G, layer D, sample VII, 150$155 \mathrm{~cm}$ above basis, showing size distribution and variability of Planorbidae, Lymnaeidae, and terrestrial gastropods as detailed in Table 2. For variations of Planorbarius sp. see also Fig. 5a-d

the taxonomical evaluation involved here is limited to identification of biological species as inferred from known morphological variability of the nearest related living species, and to faunal elements previously unrecognized or new. The ecological evaluation here is based primarily on identification of lifeform categories (Lebensformtypen, Remane 1943), which are independent of the taxonomic position.

Molluscs in general are adapted to all kinds of ecological conditions, but below the family level, molluscs, especially the terrestrial gastropods, are usually very restricted to certain habitats, which make them ideal ecological indicators. Methodologically, this is the first attempt to use detailed ecological data from recent molluscan faunas to extrapolate to the ecological conditions of a fossil community from the Lower/Middle Miocene Upper Freshwater Molasse. However, similar palaeoecological studies have been conducted for mollusc faunas elsewhere, e.g., for the Upper Miocene of the Pannonian Basin (Lueger 1981; Fordinál 1996), the Pliocene of Italy (Esu and Ciangherotti 2004) and Spain (Albesa et al. 1997), and the Quaternary of the Czech and Slovak Republics (Ložek 1964). The results presented in this work underscore the powerful potential of terrestrial fossil mollusc faunas for ecological analysis in general.

\section{Materials and methods}

Locality data and lithological details of the fossil site Sandelzhausen (near Mainburg, Bavaria, southern Germany)
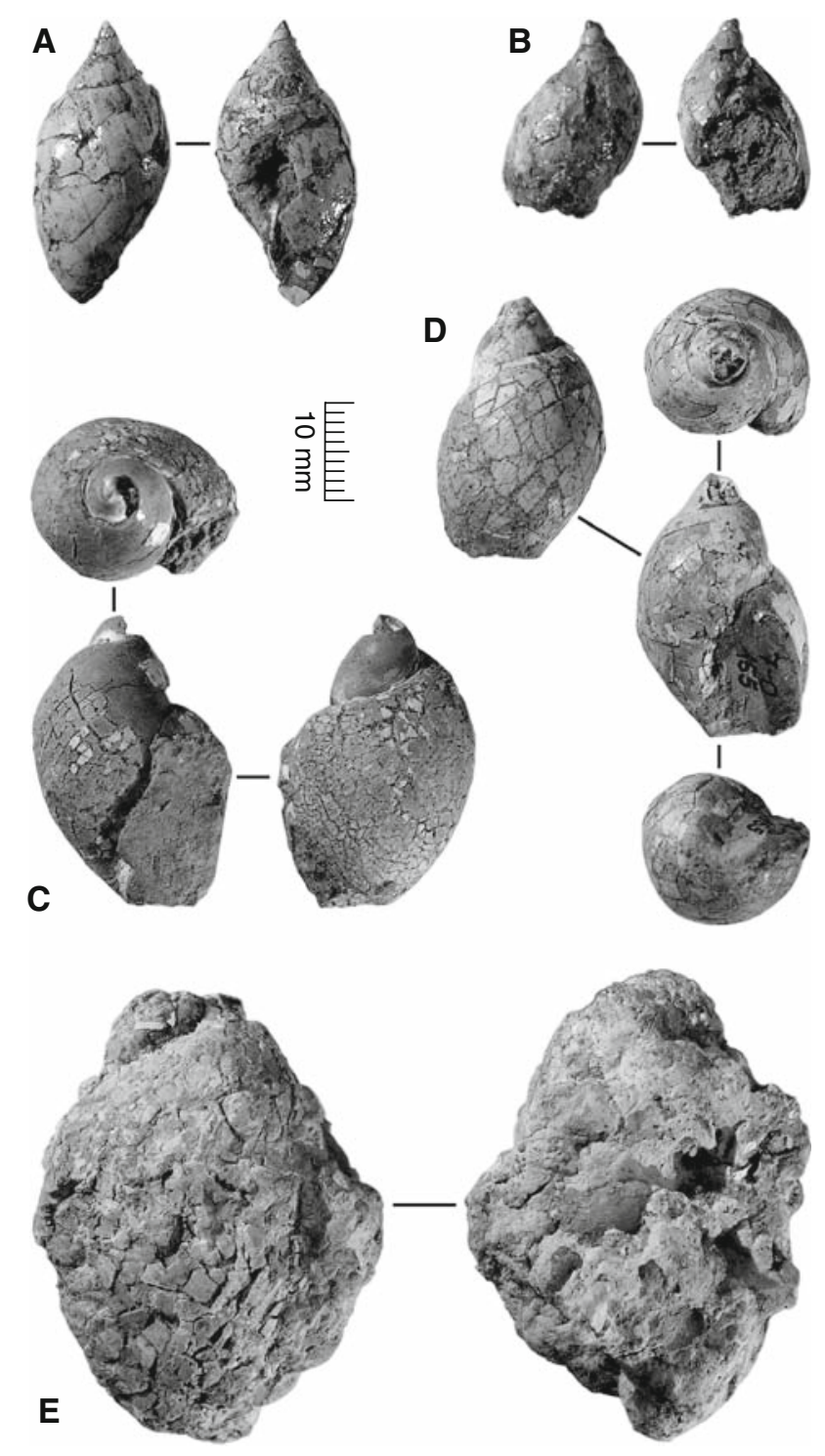

Fig. 3 Lymnaeidae. a Lymnaea sp. (BSPG 1959 II 16132), det. Gall as Radix (Radix) socialis dilatata (Noulet); location PQ 5-F, 95$110 \mathrm{~cm}$ above basis (layer C); original to Gall (1972, 15). b Radix sp. (BSPG 1959 II 16133), det. Gall as Radix (Radix) socialis dilatata (Noulet); location PQ 5-F, 95-110 cm above basis (layer C); original to Gall (1972, 15). c Radix sp. (BSPG 1959 II 16134), det. Gall as Radix (Radix) socialis dilatata (Noulet); location PQ 4-O, $155 \mathrm{~cm}$ above basis (base of layer D); original to Gall (1972, 15). d Radix sp. vel Stagnicola sp. (BSPG 1959 II 465), det. Gall Radix (Radix) socialis dilatata (Noulet); location PQ 7-O, $155 \mathrm{~cm}$ above basis (base of layer D); figured in Gall (1973, pl. 1, Fig. 10). e Lymnaeidae gen. et sp. indet. (BSPG 1959 II 466), det. Gall Radix (Radix) cf. socialis dilatata (Noulet); location unknown (probably layer B); figured in Gall (1973, pl. 1, Fig. 11)

have been published by Fahlbusch and Gall (1970) and Fahlbusch et al. (1972). Their nomenclature of fossiliferous horizons (layers A-D, with sublayers) is used throughout the present text (Fig. 1). All previous work conducted on the fossil site Sandelzhausen up to 2002 has been summarized by Fahlbusch (2003) and Moser et al. (2009 this volume). 

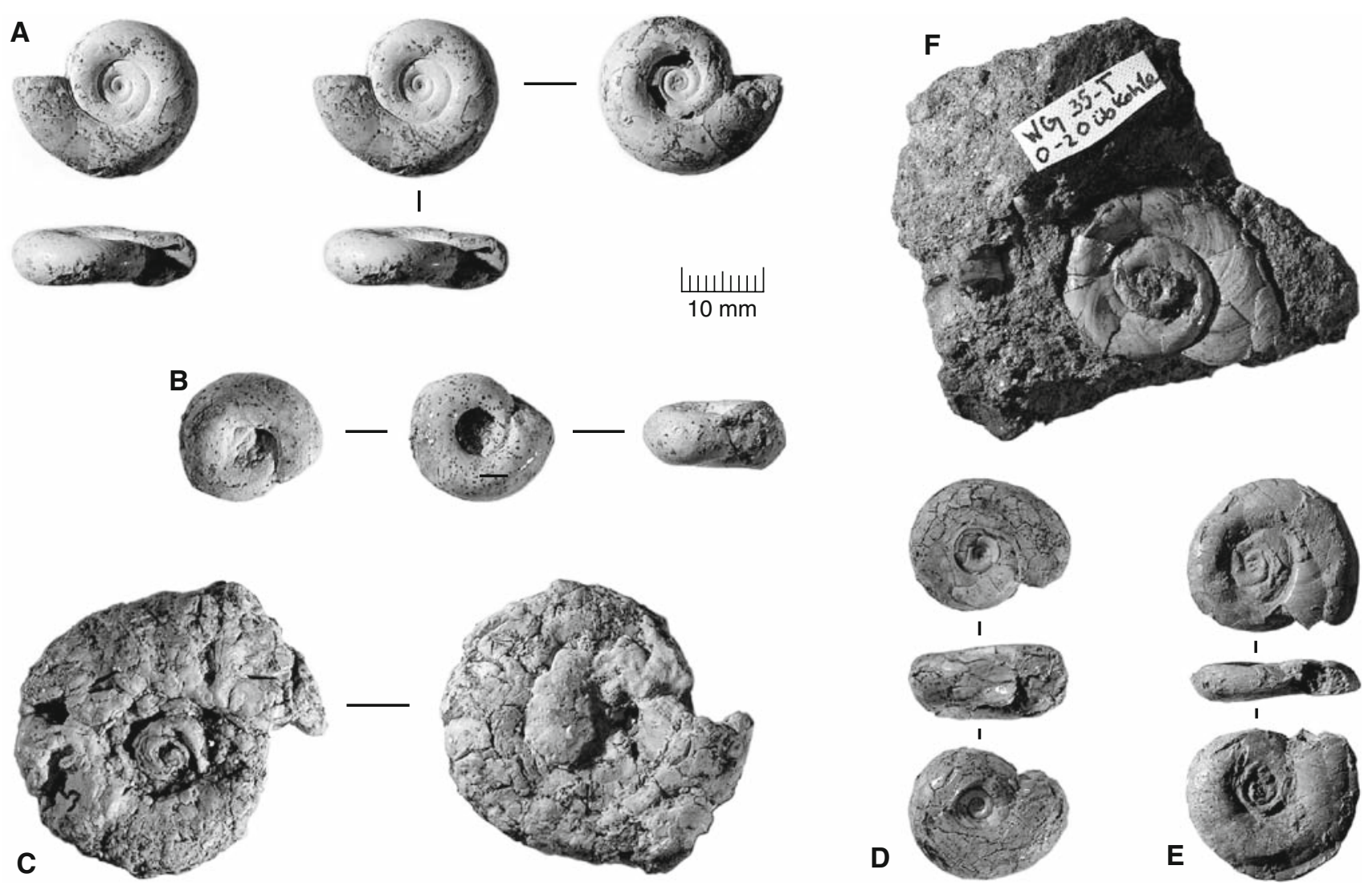

Fig. 4 Planorbidae I (big). a Planorbarius sp. (BSPG 1959 II 462), det. Gall as Planorbarius cornu mantelli (Dunker); location PQ 11-F, $140 \mathrm{~cm}$ above basis (layer D); figured in Gall (1973, pl. 1, Fig. 7). b Planorbarius sp. (BSPG 1959 II 16135), det. Gall as Planorbarius cf. sansaniensis (Noulet); location PQ 4-N, $120 \mathrm{~cm}$ above basis (layer B2]; original to Gall $(1972,16)$. c Planorbarius sp. (BSPG 1959 II 463), det. Gall as Planorbarius cf. cornu mantelli (Dunker); location PQ 9-K, 30-50 cm above basis (layer B1); figured in Gall

(1973, pl. 1, Fig. 8). d Planorbarius sp. (BSPG 1959 II 464), det. Gall as Planorbarius sansaniensis (Noulet); location PQ 4-N, $120 \mathrm{~cm}$ above basis (layer B2); figured in Gall (1973, pl. 1, Fig. 9). e Planorbarius sp. (BSPG 1959 II 16136), det. Gall as Planorbarius cornu mantelli (Dunker); location PQ 9-F, $105 \mathrm{~cm}$ above basis (layer B2 or C1); original to Gall (1972, 15). f Planorbarius sp. (BSPG 1959 II 16137), location PQ 35-T, 0-20 cm above coal layer (base of layer D)

Stratigraphically and biochronologically the age of the site has been confined as close to the Burdigalian/Langhian stage boundary (Lower/Middle Miocene boundary) and the fauna belongs to the MN5 mammal unit, but is slightly older than the reference locality Pontlevoy-Thenay (Heissig 1997, 2005). By cross-correlation (magnetostratigraphy, sequence stratigraphy, biostratigraphy) to radiometrically dated continental and marine sections a numerical age slightly older than $16 \mathrm{Ma}$ is inferred for Sandelzhausen (see Moser et al. 2009 this volume, for summary of age determinations).

All material used in this study is housed in the Bayerische Staatssammlung für Paläontologie und Geologie (BSPG), München under the collection number BSPG 1959 II. Most of the material was individually sampled in the field during the years 1969-1975 by Gall and others; however, several specimens and samples date from the earliest test excavations under Richard Dehm (collection labels reading "Grube Bergmaier") and from a test profile taken in 1966 (Fig. 1a). Additionally, screen-washed

samples (beginning 1962, Fahlbusch 2003) yielded several hundred micromolluscs. The work of Gall $(1972,1973)$ is based upon this material. A further few hundred specimens date from the years 1994-2001, most notably including the only known unionid specimens.

In addition to evaluating most of the collection material for biodiversity and distribution pattern, this work includes also quantitative analysis of old screen-washed samples previously not considered by Gall: During the last days of the first excavation season in 1969, Fahlbusch initiated detailed stratigraphical bulk sampling of 5-cm-thick layers in grid square metre PQ 10-G for separate screen-washing and sorting for biostatistical purposes (Fahlbusch and Gall 1970: 379, and unpublished field notes). Fortunately, the mollusc fractions thus retrieved from nine of these samples from the upper part of the fossiliferous horizon (e.g., Fig. 2) remained untouched and have not been investigated since. In this work, the more than 9,000 specimens contained in these quantitative samples are divided into 


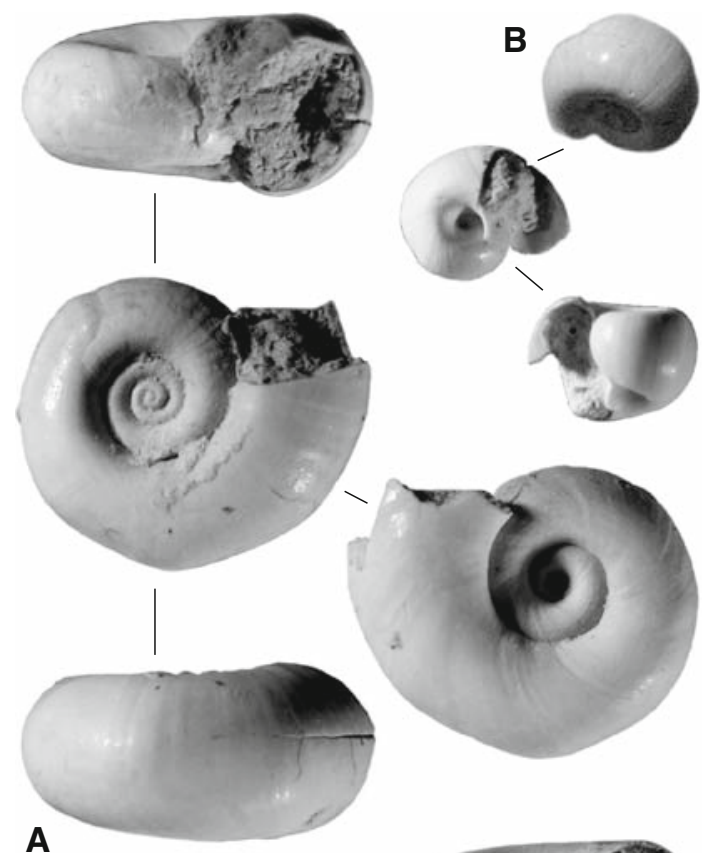

A
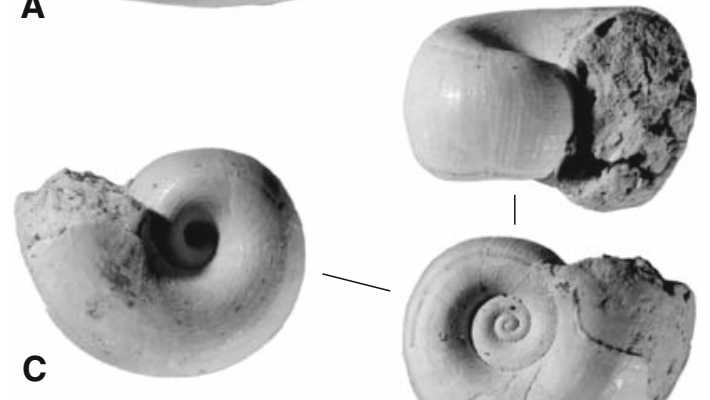

|
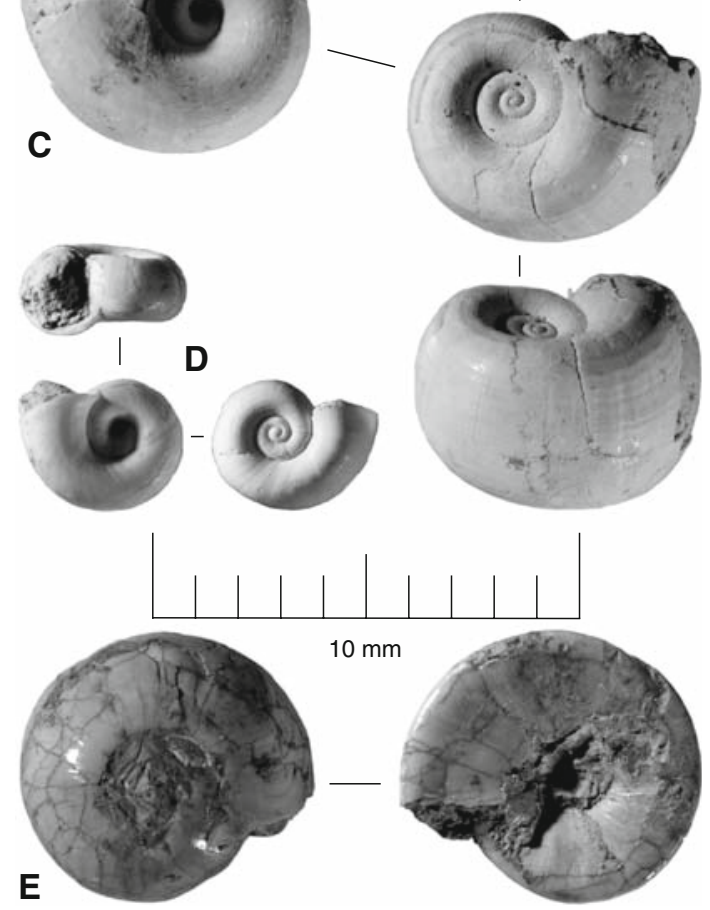

biospecies and are analyzed for ecological significance and their distribution patterns.

All photography (using Konica-Minolta Z1 and Z6) was carried out by one of the authors (M.M.), if not indicated otherwise. Ecological evaluation of the fossil
४ Fig. 5 Planorbidae II (small). a Planorbarius sp., var. I (BSPG 1959 II 16138), location PQ 10-G, sample IX, layer D, 160-170 $\mathrm{cm}$ above basis. b Planorbarius sp., var. II (BSPG 1959 II 16139), location PQ 10-G, sample IX, layer D, 160-170 cm above basis. c Planorbarius sp., var. III (BSPG 1959 II 16140), location PQ 10-G, sample IX, layer D, 160-170 cm above basis. d Planorbarius sp., var. IV (BSPG 1959 II 16141), location PQ 10-G, sample IX, layer D, 160-170 cm above basis. e Segmentina sp. (BSPG 1959 II 16142), det. Gall as Segmentina larteti larteti (Noulet); location test profile 1966 (approximately a few meters SW of grid center), layer C; original to Gall $(1972,17)$

Sandelzhausen species has been done by careful comparison with the distribution and ecological demands of closely related living species, as documented in the literature or from own observations (G.F. and H.-J.N.).

\section{Preservational considerations relating to the interpretation of the mollusc fauna}

\section{General considerations}

While documenting geological sections at Sandelzhausen 1994-2001, one of the authors (M.M.) noted several observations incompatible with the organogenic origin of the calcareous concretions hypothesized by Gall (1973). In particular, calcareous concretions are arranged in horizons sometimes crossing the sedimentary bedding plane and even can occur in the basement sands. Besides this, several forms of carbonatizations are observed, such as carbonate powder, sphaeroids, nodules, and calcrete (Moser 2000, see also Schmidt 2002), which point to a pedogenetic origin, as do also root traces (Retallack 2001). Obviously, the concretionary layers are related to water table stands and water flows within the sedimentary pile, and are rather independent of other sedimentological features. Furthermore, the nature of geod development is in essence different from the concretionary growth observed in Sandelzhausen in that, in geods, where the decomposing soft body chemically triggers the carbonatization, the hard parts of an animal are preserved in a perfectly three-dimensional state surrounded by the usually concentrically banded nodule (see, e.g., Galiana 1979, pls. 1-4). In contrast, the growth of a pedogenetic carbonate nodule bursts the fossil into pieces (Fig. 3e). Careful observations also lead to rejection of Gall's (1973) hypothesis that formation of all concretions was caused by either gastropod or vertebrate remains. It is found that carbonatization within a given horizon occurs at random and is not affected by the presence or absence of fossils. Neither is there a general correlation between gastropod specimen numbers and nodule frequency; for example, in layers $\mathrm{C} 1-\mathrm{C} 3$ of the section, no carbonate nodules occur in spite of an especially rich gastropod fauna. 

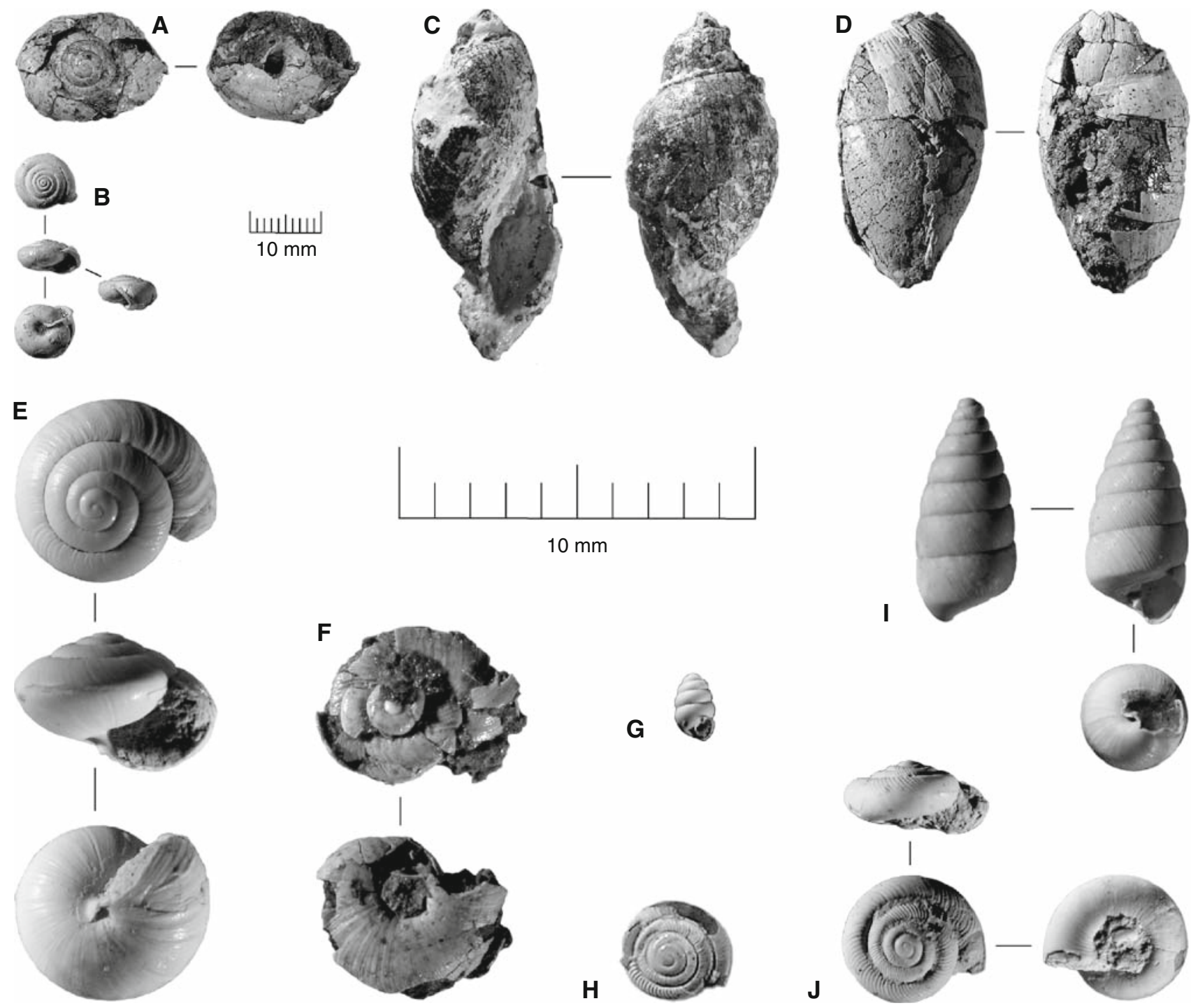
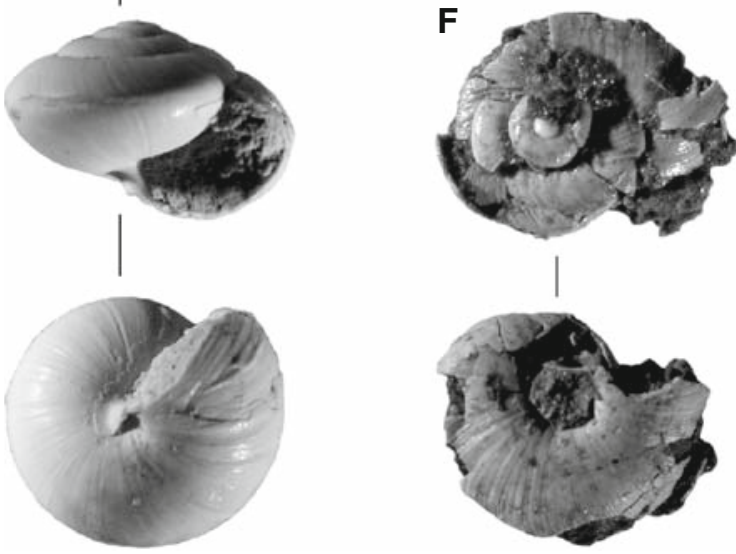

Fig. 6 Diverse gastropods. a-d: larger gastropods: $1 \times$. A Archaeozonites sp. (BSPG 1959 II 16143), det. Gall as Archaeozonites costatus costatus Sandberger; location PQ 11-J, $90 \mathrm{~cm}$ above basis (layer B2 or C); original to Gall (1972, p 7). b Soosia (Prosoosia) cf. godarti Michaud (BSPG 1959 II 16144), det. Gall as Klikia (Klikia) giengensis giengensis (Klein), from a sand lense in the western part of the locality (probably layer C3 at or near PQ 23-O); original to Gall (1972, p 10). c Palaeoglandina sp. (BSPG 1959 II 16145), location PQ 45-R, $115 \mathrm{~cm}$ above coal layer (layer D). D Palaeoglandina sp. (BSPG 1959 II 16146), det. Gall as Palaeoglandina gracilis porrecta (Gobanz), location PQ 7-N, 75-80 cm above basis (layer B1); original to Gall (1972, p 12). E-J smaller gastropods: $5 \times$.

It is of some interest here to note that bone material is on only rare occasions heavily encrusted by concretionary nodules, and due to immature state of the pedogenesis the concretions never enter the interior of the bones (i.e., the medullary cavities or spongy meshwork) and do not blow them up (for such cases see Moser 2003). However, like mollusc shells, vertebrate bones of Sandelzhausen are also mildly affected by pedogenesis and diagenesis, leading to cracking and irregular splintering (resulting from the combined action of roots, clay welling, compaction, and other diagenetic processes). The resulting jigsawed bone pattern has been observed to different degrees in a large number of Phanerozoic localities and has been erroneously attributed to subaerial weathering, sometimes even called 
"sun-cracking" (e.g., Galton 1990; Andersson \& Kaakinen 2004).

Gall (1973, Fig. 1) found that preservation, especially the flattened (crushed) and the blown-up preservation, is not randomly distributed within the gastropod fauna, but affects certain species exclusively or more often while others are rarely or not at all affected, leading him to differential habitat interpretation. Looking at the most frequent of the larger-sized gastropods of the indicated genera Tropidomphalus (three species), Cepaea (two species), Radix (three species), and Planorbarius (two species), Gall found that in each genus one of the species is (almost) missing in layer $\mathrm{C} 1-\mathrm{C} 3$ (four exceptions), while the other species are preserved almost exclusively as flattened specimens. On the other hand, the blown-up specimens of layers A to B2 belong mostly to those "species" not preserved in layer $\mathrm{C} 1-\mathrm{C} 3$. In effect, the voluminous (blown-up) specimens were assigned by Gall (1972, 1973) to other species than the flat (flattened) specimens. However, Gall (1973) only presented an explanation for the nonrandom distribution pattern of blown-up gastropods, but none for the nonrandom distribution pattern of flattened specimens. So the question arises whether the taxonomical attribution of specimens to species was correct in all cases.

Also, regarding the types of preservation distinguished by Gall (1973) in general (Fig. 1f), several field observations must be mentioned in partial objection. First, the "steinkern" preservation is not in general a kind of preservation different from the "unchanged" state but rather a different result from trying to rescue a specimen: mostly the shell fragments stick with the marl and get lost either while trying to remove the snail shell from the sediment or while the fossils dry out in the air: the shell fragments then
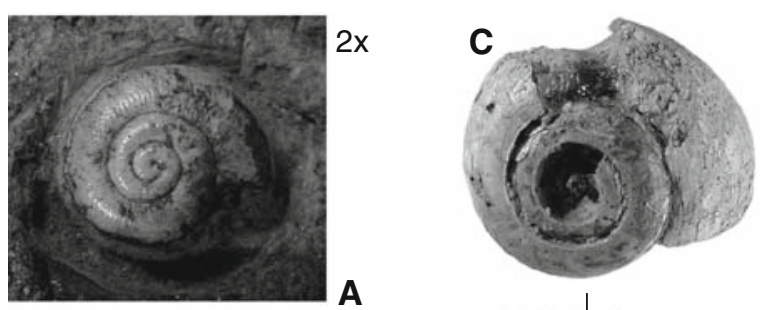

।
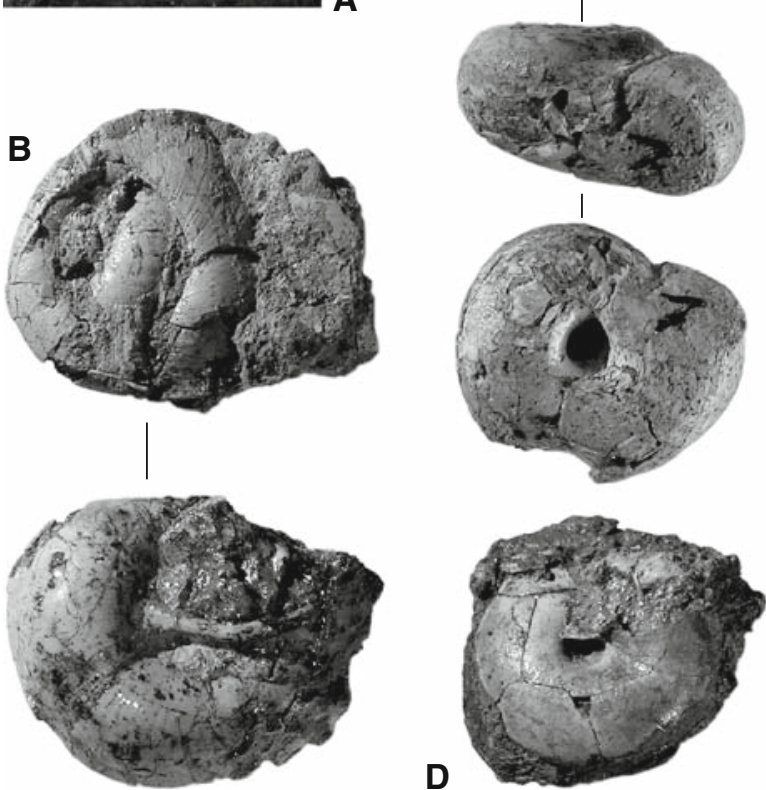

Fig. 7 Tropidomphalus. a Tropidomphalus (Pseudochlorites) sp. (BSPG 1959 II 16153), det. Gall as Tropidomphalus (Pseudochloritis) incrassatus incrassatus (Klein), location PQ 24-N, $60 \mathrm{~cm}$ above basis (layer B); original to Gall $(1972,9)$. b Tropidomphalus (Pseudochlorites) sp. (BSPG 1959 II 16154), det. Gall as Tropidomphalus ? sp. ["Gehäusebasisfläche"], location PQ 11-O, $115 \mathrm{~cm}$ above basis (layer D); original to Gall $(1972,10)$. c Tropidomphalus (Pseudochlorites) sp. (BSPG 1959 II 456), det. Gall as Tropidomphalus (Pseudochloritis) extinctus (Rambur), location PQ 12-F, $140 \mathrm{~cm}$ above basis (layer D); figured in Gall (1973, pl. 1, Fig. 1).
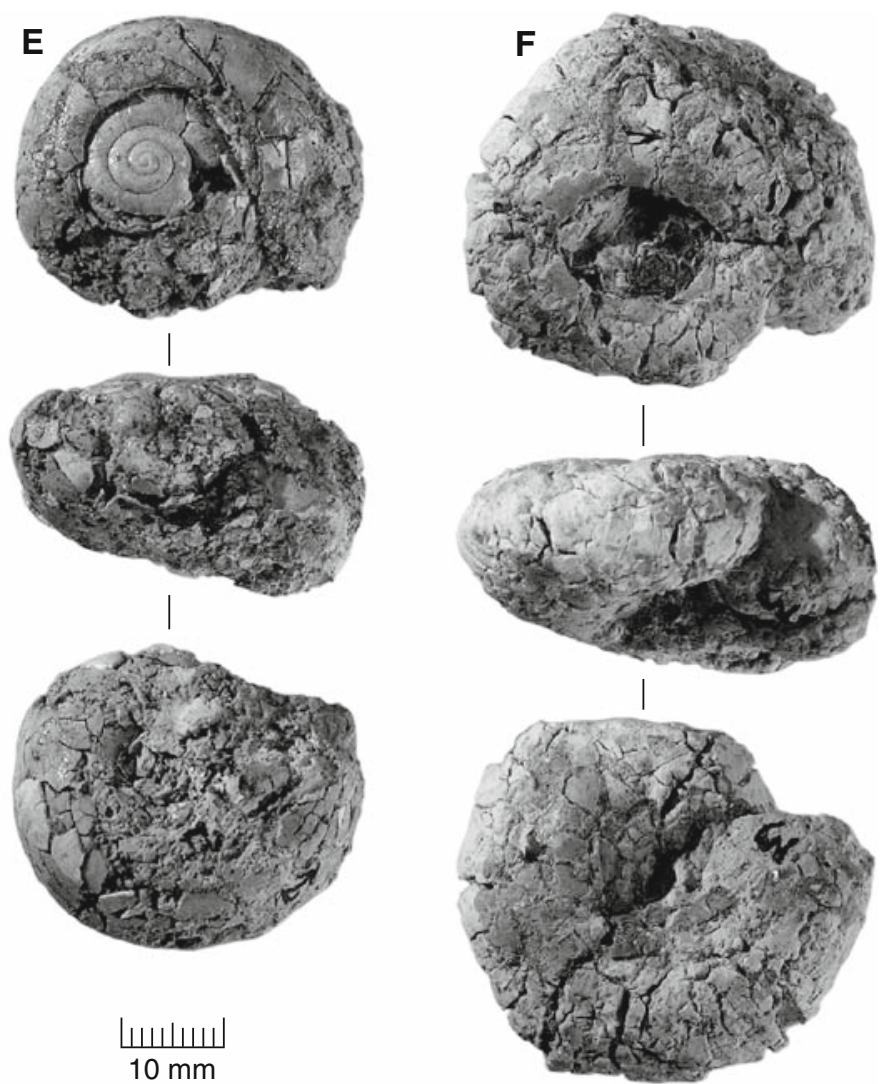

d Tropidomphalus (Pseudochlorites) sp. (BSPG 1959 II 16155), det. Gall as Tropidomphalus (Pseudochloritis) incrassatus incrassatus (Klein), location PQ 5-D, $110 \mathrm{~cm}$ above basis (layer C1); original to Gall (1972, 9). e Tropidomphalus (Pseudochlorites) sp. (BSPG 1959 II 457), det. Gall as Tropidomphalus sp., location PQ 7-O, $100 \mathrm{~cm}$ above basis (layer B2); figured in Gall (1973, pl. 1, Fig. 2). f Tropidomphalus (Pseudochlorites) sp. (BSPG 1959 II 458), det. Gall as Tropidomphalus ? sp., location unknown (probably layer B or D1); figured in Gall (1973, pl. 1, Fig. 3) 
get shed; only in few cases is there really no shell preserved. Second, the blown-up state is reached not only by concretionary carbonate growth, but also through clay welling (e.g., Figs. 4d, 8e). This is a frequently recurring process during early palaeopedogenesis and/or due to changing moisturization in rather recent times (Ice Ages), associated with movements in the sedimentary pile mediated by cryoturbation and soil movement (in prep.). Finally, the preservational types are subjectively distinguished while in fact all transitions are present.

\section{Statistical evaluation of preservation types}

To test specifically whether the blown-up preservation might not in fact be distributed randomly among the specimens, as would be expected for a purely sedimentologically influence, the different "species" of one genus are treated as if only a single biological group with differently preserved individuals was present and a statistical reevaluation then applied to the original specimen counts of Gall (1973: Fig. 1) (Fig. 1f, 10). The blown-up state is compared with other types of preservation in the six genera analyzed by Gall. Only layers B1 and B2 are suitable to analysis, however, as the layers A, C, and D each lack preservational differences that might be used for comparison. Counting all specimens across species borders, all macrogastropods together show 68\% blown-up preservation in layer B1 $(n=254)$ and $63 \%$ in layer B2 $(n=147)$. So, approximately two-thirds of all specimens are blown up, which is taken as the expectation value for the specimens of every genus in both layers (Fig. 10). In the three most common snails-the two freshwater snails Planorbarius (B1: $70 \%, n=168)$ and Radix (B1: $66 \%, n=68)$, and the terrestrial Cepaea-like snails (B1: $63 \%, n=8$; B2: $67 \%, n=12$ )-this value is met remarkably well. As expected, the correspondence is less good with lower specimen counts, which is attributable to sample size effects.

Consequences of preservational biases for taxonomy of the Sandelzhausen mollusc assemblage

It is concluded a priori that a taxonomic reevaluation must carefully take into account preservational biases obscuring the original shape of the fossils that might lead to misinterpretations. Gall already himself noted (1973: 11) although he did not follow up the implications-that "... [es] konnte in mehreren Fällen auch nicht entschieden werden, welche von den beiden aus der Fundschicht bekannten Cepaeen-Arten in expandiertem Zustand vorliegt. Die Gehäusemorphologie von $C$. silvana silvana konnte sich nämlich nachweisbar durch die Kalkkonkretionsbildung im Gehäuse... der mehr kugeligen Gestalt von
C. eversa larteti angleichen." [In several cases it was impossible to decide which of the two species of Cepaea known from the section is found blown up. In particular, the shell morphology of $C$. silvana silvana could provably become closely similar to the more spherical shape of C. eversa larteti by means of concretionary carbonate growth within the shell]. As the problematical preservation mostly affects larger-sized species, in particular Tropidomphalus, Palaeoglandina, Cepaea, Radix, and Planorbarius, it is concluded that a specific attribution of specimens to certain species is impossible in most cases and for the moment even for the best preserved shells, as a major revision of the various fossil species attributed to these genera is inevitable, too (see Appendix 1 for details).

\section{The mollusc fauna and its ecological interpretation}

The present work recognizes 69 mollusc types from Sandelzhausen, shown with their local stratigraphic distribution in the section in Table 1. Several of the recognized forms are new to Sandelzhausen or reinterpreted from the previous work by Gall (1972). Notwithstanding the major revisory work due, some preliminary taxonomic annotations to all ecospecies are found in Appendix 1.

The ecological analysis of the Sandelzhausen fossil mollusc assemblage is based on the extrapolation of the knowledge of attributes (geographic distribution, macrohabitat and microsite feature preferences and traits) of recent genera to the same or related genera as found in the fossil assemblage, using data from the literature (e.g., Ložek 1964; Falkner 1990, 1992) and field experience. Below, ecological data are listed for the freshwater and terrestrial molluscs separately, and a synthesis is to be found in the discussion section.

Ecological features attributable to the freshwater molluscs from Sandelzhausen

\section{Neritidae}

Recent animals of Theodoxus live in rithral and potamal habitats of rivers and also occur in greater lakes. In southern Europe some representatives of the genus occur in springs. Preferred water flow regime is unequivocal rheophil. The recent distribution is Europe and NW Africa to S Persia.

\section{Bithyniidae}

Bithynia species have rather modest ecological demands and are found in rivers, lakes, and also smaller water bodies 

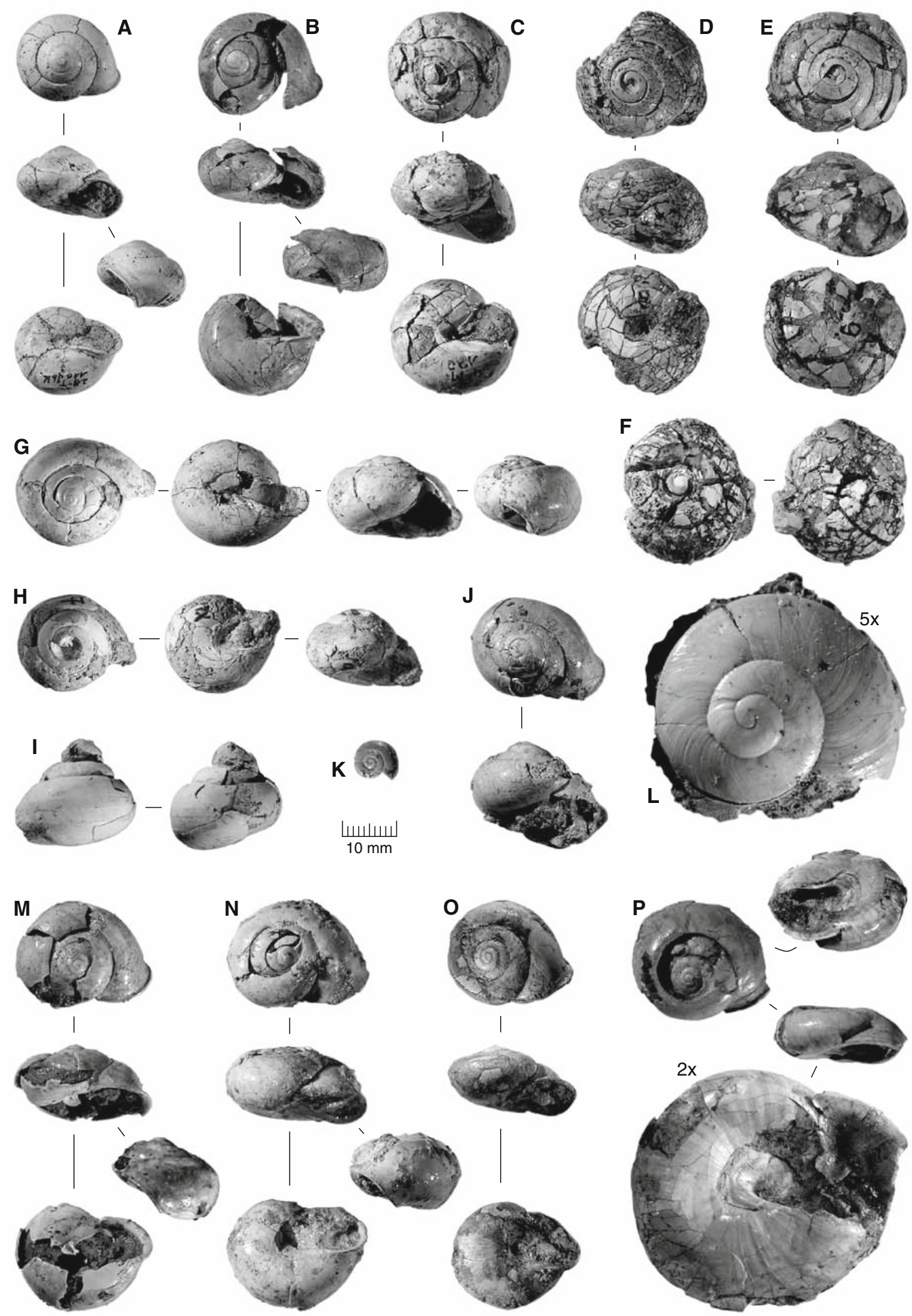
4 Fig. 8 Helicidae. a "Cepaea" sp. 1 (BSPG 1959 II 16156), location PQ 28-T, $110 \mathrm{~cm}$ above coal layer (layer D), leg. 1995. b "Cepaea" sp. 1 (BSPG 1959 II 16157), det. Gall as Cepaea silvana silvana (Klein), location PQ 8-j, $100 \mathrm{~cm}$ above basis (layer C1); original to Gall (1972, 11). c "Cepaea” sp. 1 (BSPG 1959 II 16158), det. Gall as Cepaea eversa larteti (Boissy), location PQ 4-M, $120 \mathrm{~cm}$ above basis (layer B2); original to Gall $(1972,10)$. d "Cepaea" sp. 1 (BSPG 1959 II 460), det. Gall as Cepaea eversa larteti (Boissy), location PQ 4-N, $130 \mathrm{~cm}$ above basis (layer B2); figured in Gall (1973, pl. 1, Fig. 5). e "Cepaea" sp. 1 (BSPG 1959 II 461), det. Gall as Cepaea cf. eversa larteti (Boissy), location PQ 6-N, $110 \mathrm{~cm}$ above basis (layer B2); figured in Gall (1973, pl. 1, Fig. 6). f “Cepaea” sp. 1 (BSPG 1959 II 16159), location PQ 32-V, $115 \mathrm{~cm}$ above coal layer (layer D), leg. 1995. g "Cepaea" sp. 1 (BSPG 1959 II 16160), det. Gall as Cepaea silvana silvana (Klein), location test profile 1966 (approximately a few meters SW of grid centre) (probably layer D); original to Gall (1972, 11). h “Cepaea” sp. 1 (BSPG 1959 II 459), det. Gall as Cepaea eversa larteti (Boissy), location unknown (probably layer D); figured in Gall (1973, pl. 1, Fig. 4). i “Cepaea” sp. 1 (BSPG 1959 II 16161), location PQ 33-U, $110 \mathrm{~cm}$ above coal layer (layer D), leg. 1994. j “Cepaea" sp. 1 (BSPG 1959 II 16162), location PQ 27-T, $5 \mathrm{~cm}$ below coal layer (layer C1), leg. 1994. k "Cepaea" sp. indet. (BSPG 1959 II 16163), location PQ 30-V, 0-10 cm below coal layer (layer C1), leg. 1995. I "Cepaea” sp. indet. (BSPG 1959 II 16164), location PQ 35-U, coal layer (layer C2), leg. 1997. m "Cepaea" sp. 2 (BSPG 1959 II 16165), det. Gall as Cepaea silvana silvana (Klein), location PQ 8-M, 55-60 cm above basis (layer B1); original to Gall (1972, 11). n "Cepaea" sp. 2 (BSPG 1959 II 16166), det. Gall as Cepaea silvana silvana (Klein), location PQ 11-O, $115 \mathrm{~cm}$ above basis (layer C1); original to Gall $(1972,11)$. o "Cepaea" sp. 2 (BSPG 1959 II 16167), location PQ 32-V, 25-35 cm below coal layer (layer B2), leg. 1995. p "Cepaea” sp. 2 (BSPG 1959 II 16168), det. Gall as Hemicycla asperula cf. leymerieana (Noulet), location PQ 6E, $115 \mathrm{~cm}$ above basis (layer C2); original to Gall $(1972,10)$

which can even be temporary. There is no particular preference for flow regimes. The genus is common in nearly all continents, except the Americas.

\section{Valvatidae}

Representatives of Valvata (Cincinna) have nearly the same ecological requirements as those of Bithynia; they live variously in rivers, lakes, and smaller water bodies. There are only few recent species which do not endure drought. Other recent species of Valvata (Cincinna) are especially adapted to land-water interface area and droughts do not impose problems for them. The preference is more towards lentic (limno- to rheophil) water flow regimes. The genus occurs throughout the northern hemisphere.

\section{Lymnaeidae}

Among the Lymnaeidae the genus Galba is a good indicator for small and smallest water bodies of the floodplains of rivers, in the wet surroundings of lakes and springs. The animals can live under lentic conditions. The recent genus has a holarctic distribution. Recent representatives of the two lymnaeid genera Stagnicola and Omphiscola are the most typical elements for floodplains. Both prefer peaty, temporary water bodies. For copulation the individuals often leave water. Though they prefer more lentic waters, they can also withstand lotic conditions. Recent distribution is west-palaearctic to palaearctic. The representatives of the modern genus Radix live in peaty waters on muddy, or stony, ground near the bank of rivers, lakes, and smaller water bodies. Some recent species endure dry conditions better and the majority are calciphile. They inhabit lentic and lotic flow regimes equally. Distribution is holarctic. Recent animals of Lymnaea s. str. endure longer droughts
Fig. 9 Unionidae. Unionidae gen. indet., sp. nov. (BSPG 1959 II $12301 \& 12302)$, location PQ 27-U, $25 \mathrm{~cm}$ above coal layer (layer D), leg. 1994. a right valve (BSPG 1959 II 12301). b fragments of the left valve (BSPG 1959 II 12302) of the same specimen, which were removed to reveal the hinge of the right valve

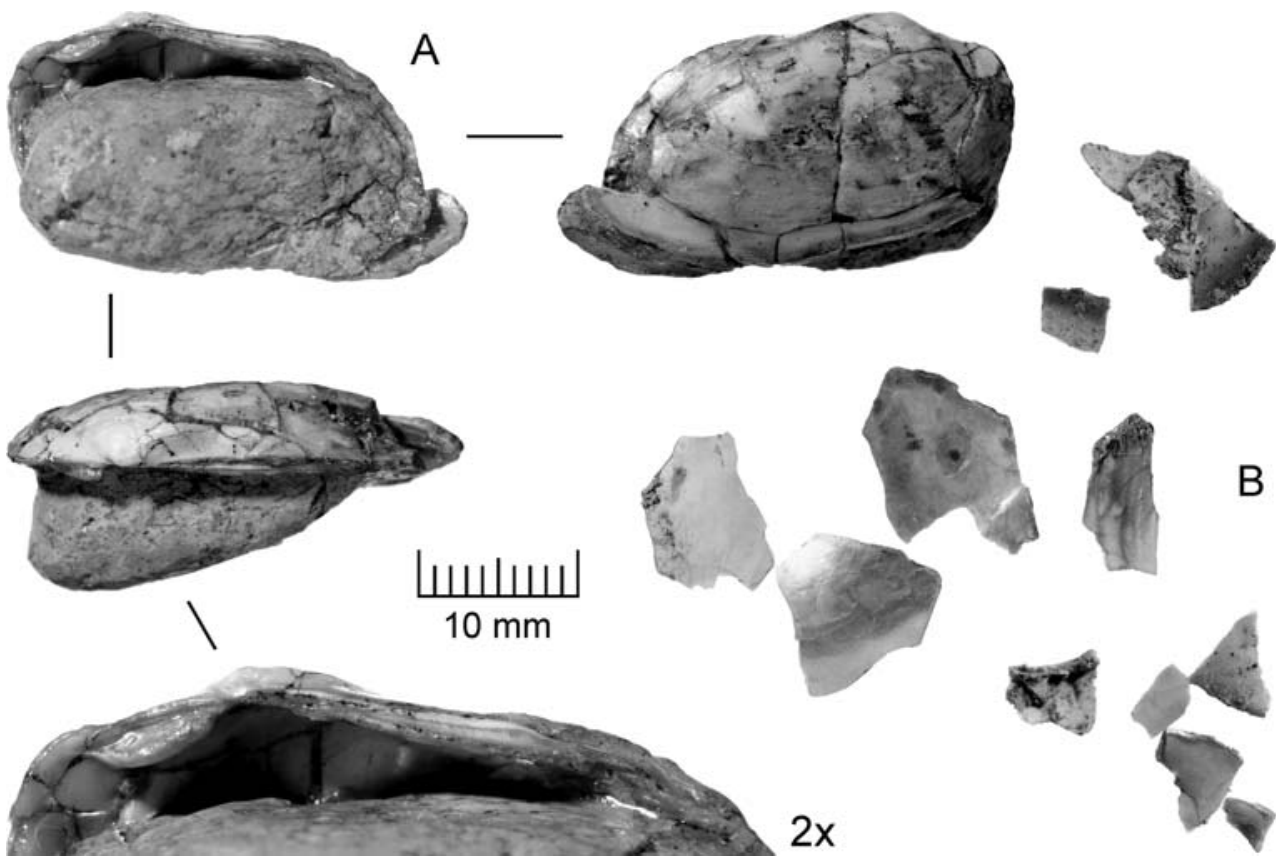


Fig. 10 Frequency distribution of blown-up preservation of snail shells in layers B1 and B2 using the specimen counts of Gall (1973: Fig. 1, new material and revisions neglected). Twothirds of the complete sample of gastropods show signs of carbonate growth or clay welling in both layers. For statistical reasons, this expectancy value is fitted the more, the larger selected taxonomic subset samples of Gastropoda are (consecutively ordered from below to above: the rare terrestrial snails Palaeoglandina,

Archaeozonites,

Tropidomphalus, Cepaea, the abundant freshwater snails Radix and Planorbarius, and summaries for these groups)
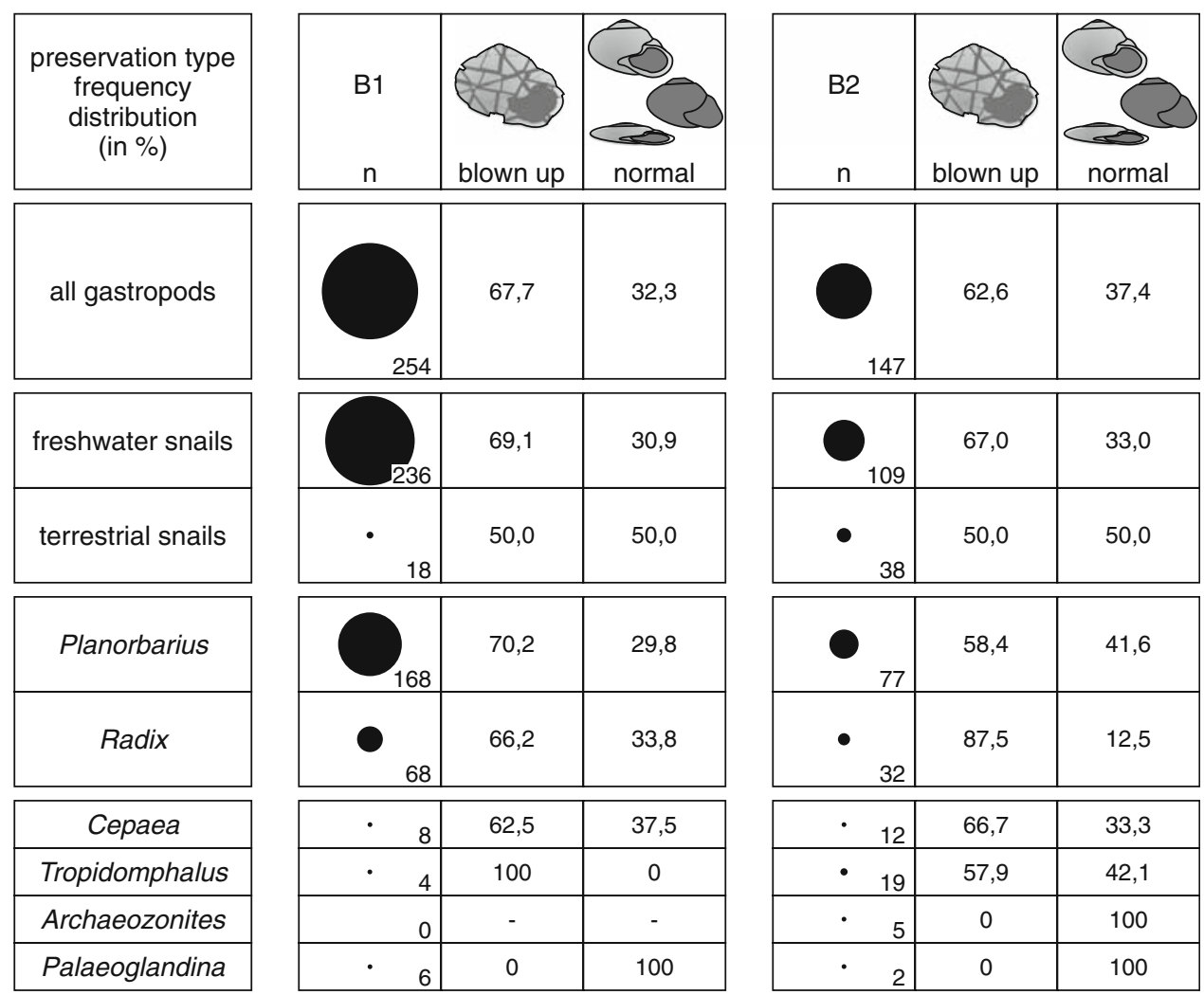

\begin{tabular}{|rr|c|c|}
\hline & 12 & 66,7 & 33,3 \\
\hline$\cdot$ & 19 & 57,9 & 42,1 \\
\hline$\cdot$ & 5 & 0 & 100 \\
\hline$\cdot$ & 2 & 0 & 100 \\
\hline
\end{tabular}

only in their early juvenile stages and are therefore typical for larger water bodies. As in the genus Radix, the distribution of Lymnaea is holarctic. The fossil shells of Radix and the stagnicoline group from Sandelzhausen often show signs of aestivation. This characteristic is highly indicative for seasonally occurring droughts of a longer duration.

\section{Planorbidae}

Most abundant among the freshwater molluscs from Sandelzhausen are the planorbids. Recent Planorbarius occur in lentic peaty waters and withstand droughts. Distribution is European to Siberian. Menetus (Dilatata) is also typical for lentic peaty waters. Some recent species can endure droughts and these are also capable of existing in slowly flowing waters. The subgenus Dilatata Clessin (Micromenetus C. F. Baker is a younger synonym, see Appendix 1) has been reported to occur in the eastern part of North America from Massachusetts to Florida (Baker 1945: 189). Today the recent species Menetus (Dilatata) dilatatus (Gould) is distributed all over the world. For the subspecies Menetus (Dilatata) dilatatus avus (Pilsbry) found in Haiti and Jamaica, Thompson (1984: 69) remarks that it "is seldom collected because of its small size (less than $2 \mathrm{~mm}$ ) and its secretive habit of living under stones and vegetative debris."

The recent representatives of the genus Drepanotrema are typical for peaty, lentic water and they do not occur in temporary water bodies. They never live in the main channel(s) of rivers, but occur abundantly in permanent water bodies associated with rivers (Harry and Hubendick 1964: 25-26). According to Starmühlner (1988: 302-303) some recent species can endure dry conditions and, in general, water bodies inhabited by Drepanotrema are in the vicinity of rivers. He also reports precisely measured temperatures for these waters: between $24.3^{\circ} \mathrm{C}$ and $28.5^{\circ} \mathrm{C}$ (Starmühlner 1988: 303, 306, 307). This today purely American genus has a recent distribution from southern Texas southward through Central America and the West Indies to the tropical and subtropical parts of South America. However, the specimens found in Texas are designated "nonindigenous" by Turgeon et al. (1998: 323).

Gyraulus s. 1. can exist both in lentic and lotic waters. Some recent species of the genus can withstand drought. In particular, the recent species $G$. $(G$.) albus is also found in temporary water bodies, e.g., ponds. Only the taxon "Gyraulus sp. nov." from Sandelzhausen, with an observable "albus-sculpture", can more or less safely be attributed to the nominate subgenus Gyraulus s. str. The genus Gyraulus s. 1. is distributed practically worldwide, in contrast to all other planorbid genera.

The modern genus Hippeutis occurs in peaty lentic and lotic waters. Some recent species can endure dry conditions. Hippeutis is a palaearctic resident, as is Segmentina, which is limited to the lentic parts of peaty waters. Ancylus 
Table 1 Revised and enlarged Mollusc faunal list of Sandelzhausen, comprising 66 snail and 3 bivalve biospecies. The numbers refer to taxonomic annotations in Appendix 1. The stratigraphic distribution within the Sandelzhausen section is partly after Gall (1972) $($ symbol $\times)$ and partly after new material (symbol $\bullet$ ). The symbol $a$ signifies revised taxonomic assignment of the original material of
Gall (1972, 1973; see numbered annotations in Appendix 1 for details). The inverted question mark is used for singular specimens probably not originating from Miocene times (see annotations in Appendix 1). The symbol size indicates specimen numbers in three categories: rare (0-10), common (11-100), and abundant (more than 100 specimens)

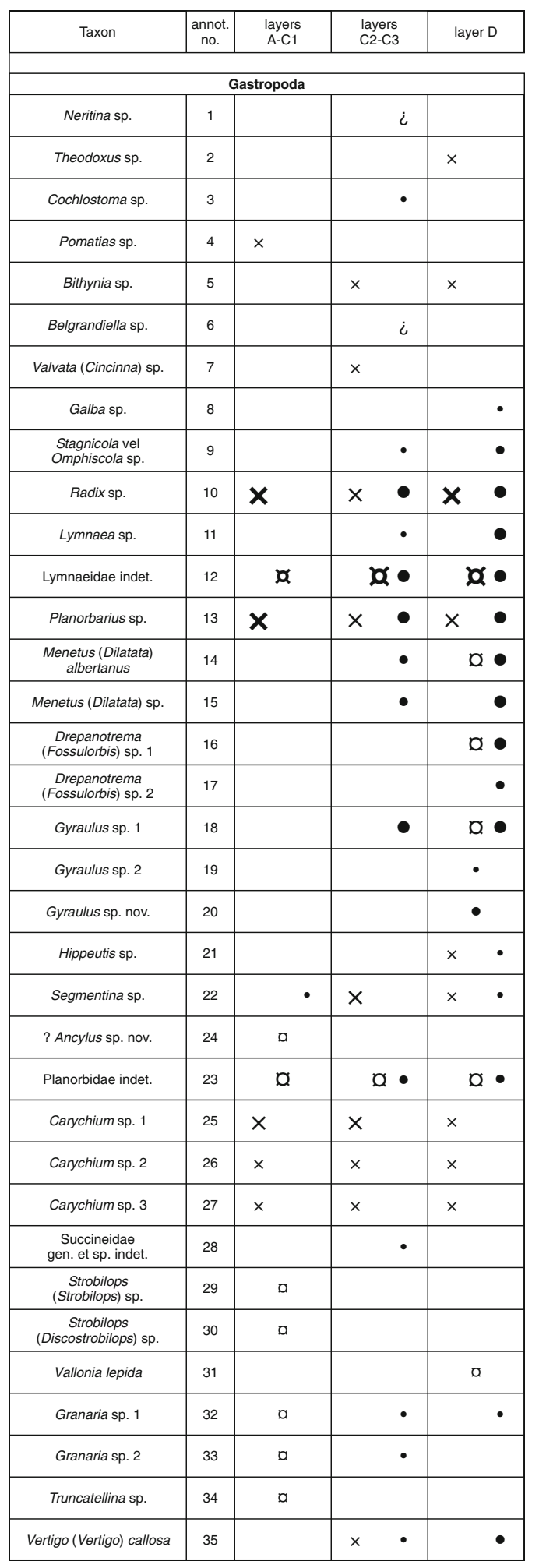

\begin{tabular}{|c|c|c|c|c|c|c|}
\hline Taxon & $\begin{array}{l}\text { annot. } \\
\text { no. }\end{array}$ & $\begin{array}{l}\text { layers } \\
\text { A to C1 }\end{array}$ & \multicolumn{2}{|c|}{$\begin{array}{l}\text { layers } \\
\text { C2-C3 }\end{array}$} & \multicolumn{2}{|c|}{ layer D } \\
\hline \multicolumn{7}{|c|}{ Gastropoda } \\
\hline Vertigo sp. & 36 & & & & & • \\
\hline $\begin{array}{c}\text { Gastrocopta (Albinula) } \\
\text { acuminata }\end{array}$ & 37 & & $x$ & & $x$ & • \\
\hline $\begin{array}{c}\text { Gastrocopta (Sinalbinula) } \\
\text { nouletiana }\end{array}$ & 38 & $\times$ & $x$ & & $\times$ & $\bullet$ \\
\hline $\begin{array}{l}\text { ?Chondrinidae vel ?Enidae } \\
\text { fam., gen. et sp. indet. }\end{array}$ & 39 & $a$ & & & & \\
\hline $\begin{array}{c}\text { Clausiliidae } \\
\text { gen. et sp. indet. } 1\end{array}$ & 40 & & & $\bullet$ & & \\
\hline $\begin{array}{c}\text { Clausiliidae } \\
\text { gen. et sp. indet. }\end{array}$ & 41 & $\times$ & $x$ & $\bullet$ & $x$ & $\bullet$ \\
\hline ? Testacella sp. & 42 & $\times$ & & & & \\
\hline Palaeoglandina sp. & 43 & $\times \quad \bullet$ & $x$ & & & \\
\hline Lucilla sp. nov. & 44 & $a$ & & & & \\
\hline Discus cf. pleuradrus & 45 & $a$ & & & & $\bullet$ \\
\hline $\begin{array}{c}\text { ?Discidae } \\
\text { fam., gen. et sp. indet. }\end{array}$ & 46 & $a$ & & & & \\
\hline $\begin{array}{c}\text { ?Endodontidae } \\
\text { fam. et gen. indet., sp. nov. }\end{array}$ & 47 & $a$ & & & & \\
\hline $\begin{array}{c}\text { ?Endodontidae } \\
\text { fam. indet., gen. nov. }\end{array}$ & 48 & & \multicolumn{2}{|c|}{$a$} & & \\
\hline $\begin{array}{l}\text { Janulus } \\
\text { cf. supracostatus }\end{array}$ & 49 & & \multicolumn{2}{|l|}{$x$} & & \\
\hline Archaeozonites sp. & 50 & $\times$ & $x$ & $\bullet$ & $x$ & $\bullet$ \\
\hline Milax sp. & 51 & & \multicolumn{2}{|c|}{$a$} & & \\
\hline Vitrina sp. nov. & 52 & & \multicolumn{2}{|c|}{$a$} & & \\
\hline Limax spp. & 53 & $\times 0$ & \multicolumn{2}{|l|}{$x$} & & \\
\hline $\begin{array}{l}\text { Soosia (Prosoosia) } \\
\text { cf. godarti }\end{array}$ & 54 & $a$ & & & & \\
\hline Soosia sp. indet. & 55 & $a$ & & & & - \\
\hline $\begin{array}{c}\text { Tropidomphalus } \\
\text { (Pseudochlorites) sp. }\end{array}$ & 56 & $\times \quad \bullet$ & $x$ & $\bullet$ & $\times$ & $\bullet$ \\
\hline Protodrepanostoma sp. & 57 & & & & \multicolumn{2}{|c|}{$a$} \\
\hline ? Helicodontidae sp. 1 & 58 & & & & & $\bullet$ \\
\hline ? Helicodontidae sp. 2 & 59 & & & & & • \\
\hline Trichiopsis sp. & 60 & & \multicolumn{2}{|c|}{$a$} & & $\bullet$ \\
\hline $\begin{array}{l}\text { Hygromiidae } \\
\text { gen. indet. sp. } 1\end{array}$ & 61 & & & & & $\bullet$ \\
\hline $\begin{array}{c}\text { Hygromiidae } \\
\text { gen. indet. sp. } 2\end{array}$ & 62 & & & & & $\bullet$ \\
\hline $\begin{array}{c}\text { Hygromiidae } \\
\text { gen. indet. sp. } 3\end{array}$ & 63 & & & & & - \\
\hline "Cepaea"sp. 1 & 64 & $\times 0$ & $x$ & & $x$ & \\
\hline "Cepaea"sp. 2 & 65 & $\times$ & $x$ & & $x$ & \\
\hline "Cepaea"sp. indet. & 66 & $x$ & $x$ & $\bullet$ & $x$ & $\bullet$ \\
\hline \multicolumn{7}{|c|}{ Bivalvia } \\
\hline $\begin{array}{c}\text { Unionidae } \\
\text { gen. indet., sp. nov. }\end{array}$ & 67 & & & & & $\bullet$ \\
\hline Sphaerium sp. & 68 & $\times$ & $x$ & & & \\
\hline Pisidium sp. & 69 & & $x$ & & & \\
\hline
\end{tabular}


is characteristic of both lotic and lentic waters and limited to wetsern parts of the Palaearctic.

\section{Unionidae}

Low-diversity unionid assemblages accompanied by sphaeriids are characteristic for moderately lotic conditions such as small tributaries or secondary channels off from the main drainage system of rivers (Scholz and Hartman 2007). The small size $(30 \mathrm{~mm})$ of the only articulated specimen found in Sandelzhausen is remarkable for this rather largesized bivalve family. The rather thick and short valve and strong hinge teeth point possibly to a short divergence time from a downstream main river unionid species adapted to higher water energy conditions.

\section{Sphaeriidae}

The smaller bivalves from Sandelzhausen are always preserved with both valves. The recent genera Sphaerium and Pisidium can live under moderate lotic conditions as well as in lentic waters, and are typically found in ponds and small lakes. Recent Sphaerium show a holarctic distribution and Pisidium is cosmopolitan.

Ecological features attributable to the terrestrial molluscs (gastropods) from Sandelzhausen

\section{Cochlostomatidae}

Recent Cochlostoma s. 1. live on rocky, calcareous ground in forests. The genus occurs from SW Europe to the Caucasus, including the Mediterranean area.

\section{Pomatiidae}

The recent genus Pomatias indicates forests with enough light (clearings, open woodland). Occurrence is western and southern Europe including the Mediterranean area.

\section{Carychiidae}

The group of ancient Pulmonates to which this family belongs is largely restricted to coastal areas; Carychium is the only genus which is more terrestrial. Carychium has a preference for damp habitats and yet several species live in the soil, on wood or leaves. The genus is today nearly cosmopolitan, excluding South America, Oceanica, and Australia.

\section{Succineidae}

The members of that family show in general an amphibious lifestyle. They prefer microsite features occurring on water-saturated ground, exposed to short periods of temporary flooding. The family occurs on all continents.

\section{Strobilopsidae}

In general, recent Strobilopsidae "live in decaying logs in moderately humid forests" (Emerson and Jacobson 1976: 220). Today, Strobilops s. str. is a purely American genus. The subgenus Discostrobilops is restricted to the warm and tropical parts of North America and the West Indies.

\section{Valloniidae}

Among the members of Vallonia s. str. there exist today species which are characteristic of dry habitats, calcareous grassland, and dunes. However, there are also species found in rather damp, grassy habitats. In the present day, the genus shows a holarctic distribution, where it is restricted to the northern areas.

\section{Chondrinidae}

Granaria s. str. is indicative of open, dry, and warm (xerotherm) grassland, mostly on calcareous rocks. Today the genus occurs in the Pre-Alps, including the foreland, as well as in SE Europe and the Mediterranean area.

\section{Vertiginidae}

European Truncatellina lives today in dry grassland or exposed ground. However, the geographical distribution of the genus encompasses holarctic regions and East and South Africa. In Africa the species ranges from drier woodland to mountain forests, in plant debris microhabitats (Herbert and Kilburn 2004). Nearly all recent species of the genus Vertigo indicate marshy wetlands, also woods. Some species live on selected sedges and rushes, sometimes close to the groundwater level. In North America, the most common species, Vertigo ovata, "prefers very moist situations on the margins of woodland ponds and streams" (Emerson and Jacobson 1976: 219). The genus has a holarctic distribution and occurs also in the West Indies and Bermuda.

\section{Gastrocoptidae}

The subgenus Gastrocopta (Albinula) occurs today only in central and eastern North America. Subgenus Gastrocopta (Sinalbinula) is a more widespreaded group in Asia including Siberia, as well as Polynesia, Micronesia, Hawaii, and Australia. Recent Albinula species prefer dryer situations, where they can live on limestones, but they also 
occur in moist situations, crawling on the lower parts of trees (Emerson and Jacobson 1976: 218). For the recent species of the genus Gastrocopta s. 1. (containing the subgenera Albinula, Vertigopsis, Privatula, and Gastrocopta) from Kansas et al. (1947: 329, 331, 334, 337, 339, $340,342,345,348-349,350)$ present essential ecological data: All these species live in the ground litter of deciduous forests and show a certain affinity to streams. In the opinion of Pilsbry (1916: 112) the recent Trans-Caucasian Gastrocopta (Sinalbinula) theeli (Westerlund) is a descendant of the fossil European $G$. (Sinalbinula), which became extinct there at the end of the Miocene. Boettger reported this species from "Transcaucasia at Poti," where it was found "in debris of the Rion" (Boettger 1889: 284). The type species of the subgenus Sinalbinula is $G$. $(S$.) armigerella (Reinhardt) from Japan. A synonym is Pupa monas Heude from China (Pilsbry 1916: 109), which is reported to live "on stone walls and rocks in the mountains south of Ning-kuo-fu." A representative of the subgenus in Africa is G. (S.) pleimesii (Jickeli), which occurs in Abyssinia at high elevations ["Habab Mtzs., Nakfa, in the gorge of Asqaq, 5,664 ft. elevation, on bits of wood under rotten leaves and stony talus" (Jickeli 1873: 107; Pilsbry 1917: 119)].

\section{Clausiliidae}

Clausiliids in general live in woodlands. Most of them live in forest litter (dead wood, twigs, and fragments of bark). The subfamily Clausiliinae has a west-palaearctic distribution.

\section{Testacellidae}

Recent species of the family are carnivorous and live subterraneously in richly organic soils. They live in burrows a few centimetres below the surface. Their activity period is at night, when they search for earthworms. Today, testacellids are mainly found in cultivated environments; in areas not influenced by Man they need the protection of the forest. The family has an Atlantic European to Mediterranean distribution.

\section{Oleacinidae}

The fossil genus Palaeoglandina belongs to the subfamily Euglandininae, which occurs still today with some representatives (e.g., the species complex of Poiretia cornea Brumati 1838) in SE Europe. Like in Testacella, the species are carnivorous but prefer dry and rocky substrates, where they live in fissures or caves. The recent Euglandina rosea (Férussac 1821), which is native to the southeastern USA, shows a completely different life-style: It is found on the ground and on trees above the floodplain of the Chipola River in Florida (Davis et al. 2004: 127). It is assumed here, based on the Lebensformtyp, that the fossil animals from Sandelzhausen had the same lifestyle as the subtropical Euglandina rosea of North America, the recent European forms being ecologically and geographically restricted relic taxa.

\section{Helicodiscidae}

The recent genus Lucilla has a holarctic distribution and is a characteristic element of moist subterranean habitats. Often the species are "generally distributed and may usually be found in leaf siftings and in drift debris on streams" (Emerson and Jacobson 1976: 241).

\section{Discidae}

Recent Discus s. str. is today a holarctic genus. In general, species of this genus live in more or less humid woodlands, especially on dead wood.

\section{Gastrodontidae}

Recent Janulus is a thermophilous, ecologically demanding relic form occurring in forests on Madeira Island.

\section{Zonitidae}

Archaeozonites is a purely fossil genus. Recent large zonitids, occurring throughout the holarctic region, live mainly in woodland. However we caution to extrapolate this habitat preference unreflected on Archaeozonites.

\section{Vitrinidae}

Vitrina spp. inhabits constantly moist soils in the holarctic region.

\section{Limacidae and Milacidae}

The species diversity in Sandelzhausen resembles the high diversity in subtropical-tropical regions. Ecologically, slugs are adapted to various conditions, but all species depend on permanent availability of moisture.

\section{Elonidae}

The recent Soosia diodonta is distributed in northern Serbia and southern Romania and lives in humid forests preferentially under dead wood. The genus Elona was reported by Gittenberger (1979) occurring in Brittany (France) and Northern Spain, often living on crystalline ground. Despite 
being one of the common forms of Sandelzhausen, the large-sized, extinct genus Tropidomphalus can only tentatively be referred to Elonidae; an ecological interpretation based on this assumed relationship is not warranted. The Lebensformtyp of Tropidomphalus more likely suggests a way of life like strong-shelled Balkanese representatives of Ariantinae.

\section{Helicodontidae}

Referral of Sandelzhausen material is as yet uncertain.

\section{Hygromiidae}

Recent hygromiids generally prefer litter grounds with bushes or tall herbs in woodlands. They are not, however, confined to particular conditions of aridity or humidity. The high diversity of four species in Sandelzhausen is comparable to the diversity of ecologically specialized species of woodlands of the Caucasus.

\section{Helicidae}

The generic name Cepaea is used in the present work to indicate snails with a Cepaea-like shell morphology. Recent Cepaea s. str. in Europe is an Atlantic faunal element and originally occurs in river valleys. The recent species of Cepaea s. str. preferentially inhabit dryer bushy land and sparse forests, but they occur also in shadowy forests and even on blank rock up to 2,000 m (Falkner 1990).

\section{Analysis of the molluscs from quantitative samples}

Preconsiderations concerning taphonomical effects

The first ca. $25 \mathrm{~cm}$ of the Sandelzhausen section above the "coal," a dark lignitic bed ("C2") of variable thickness ( 0 $8 \mathrm{~cm}$ ), has been termed "layer C3" due to its brownish appearance and lack of carbonates, similar to layer $\mathrm{C} 2$. Above layer C3, layer D is established with greenish-grey marls and is rather homogenous throughout the section except for changing carbonate content. The layer terminology initially coined is retained here, but it is noted that layer "C3" is just the initial part of the same sequence as layer "D" (this sequence has been called "obere Geröllmergel" by Fahlbusch 2003 and earlier refs.), with some diagenetically-pedogenetically induced color alterations probably due to humic acids provided by rottening wood in the surroundings or from layer $\mathrm{C} 2$.

From field observations the macrofossil content-as well as the distribution of grain sizes—within the sequence
C3-D, appears to be randomly distributed as far as vertebrate fossils (mostly disarticulated and oftenly worn) are concerned. However, the mollusc shell frequency changes by an order of magnitude within a few centimetres. This could be explained in various ways:

(A) The frequency of the molluscs in the area is in fact rather constant but the sedimentation rates vary to a large degree (e.g., annually or irregular flooding events) despite a homogenous lithological appearance, which could be the result of diagenetical obscuration of features. Thus the frequency of the molluscs would be a direct measure for the sedimentation rates and would provide a rough idea of how long a time interval is represented by the section.

(B) The sedimentation rate is rather constant, but ecological conditions fluctuate considerably, resulting in more or less flourishing mollusc assemblages.

(C) The frequency distribution pattern of the molluscs is the result of a mixture of sedimentological and ecological influences.

Hypothesis A would gain some support if the mollusc samples show a random distribution of species, indicating unchanged ecological conditions throughout the section. Especially, the proportion of terrestrial to freshwater gastropods must be considered an important indicator, as the percentage of terrestrial snails should rise with sediment influx. However, as will be seen below, the number of terrestrial snails per sample (all of same volume) does not change significantly, and therefore sedimentation rates of the consecutive samples were likely constant as well-in agreement with the homogenous distribution of particle sizes. Therefore, we assume that the composition of the mollusc fauna and the frequency of individuals largely reflect ecological fluctuations of the living community (hypothesis B).

Numerical analysis of the composition of the quantitative samples

A total of 9,384 gastropod individuals has been derived from nine quantitative samples (I-IX, see Fig. 1e for stratigraphic position). The number of individuals of terrestrial and planorbid gastropod species in the quantitative samples is indicated in Table 2 together with their habitat preference. The lymnaeids consist of mostly juvenile shells difficult to assess taxonomically and are therefore not separated into species, but counted as a group. The following observations are derived from an analysis of the quantitative distribution of gastropods:

1. The samples can be grouped according to the whole number of indiviuals per sample (=sample size) into 
Table 2 Number of specimens and stratigraphic distribution of the gastropod fauna within quantitative samples I-IX from Sandelzhausen, PQ $10-\mathrm{G}$

\begin{tabular}{|c|c|c|c|c|c|c|c|c|c|}
\hline \multirow{2}{*}{$\begin{array}{l}\text { A } \\
\text { Specimen numbers of terrestrial gastropods }\end{array}$} & \multicolumn{9}{|c|}{ Sample } \\
\hline & I & II & III & IV & $\mathrm{V}$ & VI & VII & VIII & IX \\
\hline Cochlostoma sp. & & & & 1 & & & & & \\
\hline Granaria sp. 1 & 1 & 4 & 1 & & & 1 & & & \\
\hline Granaria sp. 2 & & & 1 & & & & & & \\
\hline Vertigo (Vertigo) callosa & & & 1 & & & & 5 & 11 & 6 \\
\hline Vertigo sp. & & & & & 1 & & & & \\
\hline Gastrocopta (Albinula) acuminate & & & & & & & 1 & 1 & 1 \\
\hline Gastrocopta (Sinalbinula) nouletiana & & & & 2 & 1 & & 13 & 25 & 9 \\
\hline Clausiliidae sp. 1 & & 1 & & & & & & & \\
\hline Clausiliidae sp. 2 & 13 & 52 & 42 & 4 & 10 & 2 & 24 & 13 & 7 \\
\hline Discus cf. pleuradrus & & & & & & & & 1 & \\
\hline Archaeozonites sp. & 1 & & & & & 1 & & & \\
\hline Soosia sp. indet. & & & & & & & & & 1 \\
\hline Tropidomphalus (Pseudochlorites) sp. & & 1 & & & & & & & \\
\hline ? Helicodontidae sp. 1 & & & & & & & & 1 & \\
\hline ? Helicodontidae sp. 2 & & & & & & & & 1 & \\
\hline Trichiopsis sp. & & & & & & & 1 & 3 & 17 \\
\hline Hygromiidae sp. 1 & & & & & 1 & 1 & & 1 & \\
\hline Hygromiidae sp. 2 & & & & & & & 1 & 1 & 1 \\
\hline Hygromiidae sp. 3 & & & & & & & & & 1 \\
\hline "Сераеа" sp. indet. & 1 & & & & & & 1 & 1 & \\
\hline
\end{tabular}

B Sample

\begin{tabular}{lllllllllll}
\cline { 2 - 8 } Specimen numbers of planorbid & I & II & III & IV & V & VI & VII & VIII & IX
\end{tabular}

Habitat preference (see caption for key to numbers)

freshwater gastropods

\begin{tabular}{|c|c|c|c|c|c|c|c|c|c|c|c|}
\hline Planorbarius sp. & 9 & 6 & & 8 & 6 & 10 & 48 & 48 & $8, \underline{9}, 10$ & & \\
\hline Menetus (Dilitata) albertanus & 1 & 24 & 26 & 31 & 26 & 24 & 218 & 268 & $(8), \underline{9},(10)$ & & \\
\hline Menetus (Dilatata) sp. & 4 & 17 & 10 & 20 & 19 & & 14 & 11 & $(8), \underline{9},(10)$ & & \\
\hline Drepanotrema sp. 1 & & & & & 2 & 15 & 207 & 309 & $\underline{9}$ & & \\
\hline Drepanotrema sp. 2 & & & & 1 & 1 & & 10 & 48 & $\underline{9}$ & & \\
\hline Gyraulus sp. 1 & 15 & 128 & 108 & 326 & 475 & 83 & 1493 & 993 & $(8), \underline{9}, 10$ & & \\
\hline Gyraulus sp. 2 & & & & & & & & 4 & $(8), \underline{9}, 10$ & & \\
\hline Gyraulus sp. nov. & & & & & & & 1 & 15 & $(8), \underline{9}, 10$ & & \\
\hline Hippeutis sp. & & & & & & & 4 & 1 & $(8), \underline{9},(10)$ & & \\
\hline Segmentina sp. & & & & & & & & 1 & $\underline{9}$ & & \\
\hline $\mathrm{C}$ & Sample & & & & & & & & & & $\sum$ \\
\hline Specimen numbers for: & I & II & III & & IV & V & VI & VII & VIII & IX & \\
\hline$\sum$ Terrestrial Gastropoda & 16 & 60 & 44 & & 6 & 13 & 6 & 46 & 58 & 43 & 292 \\
\hline$\sum$ Planorbidae & 29 & 175 & 144 & & 386 & 529 & 132 & 1,995 & 1,677 & 1,176 & 6,243 \\
\hline$\sum$ Lymnaeidae & 195 & 199 & 65 & & 275 & 429 & 178 & 599 & 553 & 356 & 2,849 \\
\hline$\sum$ Gastropoda & 240 & 434 & 253 & & 667 & 971 & 316 & 2640 & 2,288 & 1,575 & 9,384 \\
\hline
\end{tabular}

$A$ land snails, $B$ planorbids. $C$ summary of all gastropods. The inferred ecological requirements for fossil biospecies are derived from the known preferences of the corresponding recent Lebensformtyp. Habitat preferences: $1=$ open gravel fields (scrubland succession); $2=$ semi-open scrub; 3 = closed-canopy forests; $4=$ ground with tall scrub; $5=$ rotting wood; $6=$ ground litter, mosses, root-felts; $7=$ sedge $\&$ rush zone; $8=$ drought compatible; $9=$ lentic waters; $10=$ lotic waters. Numbers in parenthesis indicate habitat persistence, underlined numbers indicate main or only habitat preference (see text for details) 
three clusters: low (samples I-III and VI, between 240 and 434 specimens), intermediate (samples IV and V, 667 and 971 specimens), and high (samples VII-IX, between 1,575 and 2,640 specimens) individual numbers. These three sample clusters correspond to the stratigraphic order of these samples (Fig. 1) within layers C3 (samples I-III) and D (remaining samples) defined lithologically with the exception of sample VI. The later local subdivision of layer D into D1 and D2 sensu Fahlbusch et al. (1972) further east than PQ 10G has not been applied uniformly in the locality; however, quite probably, the samples VII-IX do correlate with the base of D2.

2. The percentage frequency of the three main groups, the terrestrial, planorbid, and lymnaeid gastropods in each sample, respectively, is shown in Fig. 11. Immediately, the three clusters observed already from sample size (1), can be recognized again: the larger samples VII-IX of D2 are dominated by planorbids, the samples I-III (C3) and VI have a high proportion of lymnaeids and/or terrestrial gastropods, and samples IV and V are intermediate (D1).

3. From samples I-III, and once more between samples VI and VII, the lymnaeids apparently drop dramatically in abundance. However, this is partly

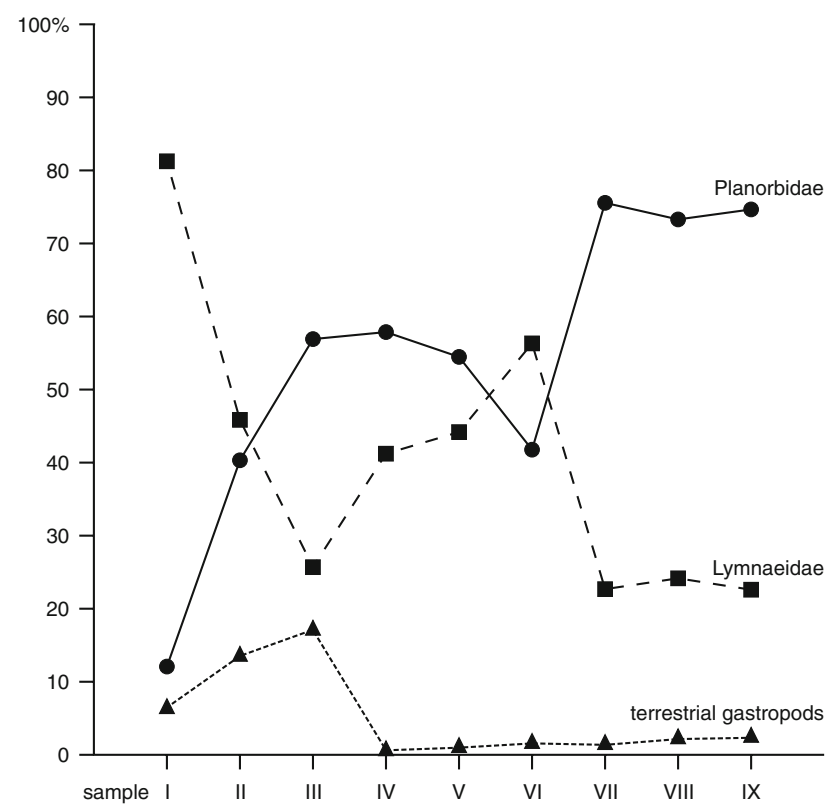

Fig. 11 Composition of the gastropod fauna in the quantitative samples I-IX from PQ 10-G, Sandelzhausen fossil site. Terrestrial gastropods apparently diminish to around $2 \%$ of the fauna after sample III; however, this is due to a general rise in the abundance of freshwater snails while the specimen numbers of terrestrial snails in fact remain nearly constant. Lymnaeids show dramatic decrease from samples I-III and VI-VII, respectively, while planorbids show inverse trends
Fig. 12 Palaeoenvironmental interpretation derived from the statistical analysis of the gastropod fauna of quantitative samples I to IX from PQ 10-G, Sandelzhausen fossil site. a The abundance of planorbids and the sample size are positively correlated. The shift from a lymnaeid-dominated to a planorbid-dominated fauna is interpreted as reduction of temporary ponds in the surroundings and increasing lake character for the Sandelzhausen site itself. b The abundance of the allochthonous and semiautochthonous terrestrial snails drops by a factor of ten between sample III and IV when compared with the autochthonous planorbids. Qualitatively, the presence of ecological indicator species for certain terrestrial habitats on the one hand and certain water body characters on the other hand show independent distribution. c Summarized schematic presentation of the decoupled environmental preference spectrum seen in the terrestrial and the two freshwater snail groups

due to the rise (or recovery) of planorbids. Thus the two freshwater snail groups show inverse abundance trends (Fig. 11).

As the sample size ( $\mathrm{G}=$ all gastropods) is clearly recognized here as a discriminating factor, bivariate analysis is performed using abundance relations of the three gastropod groups $(\mathrm{T}=$ terrestrial snails, $\mathrm{P}=$ planorbid snails, $\mathrm{L}=$ lymnaeid snails) against sample sizes (Fig. 12) instead of applying a multivariate correspondence analysis of the abundance pattern, which would yield artificial factors difficult to explain (cf., e.g., Magnin 1993: Figs. 3, 6, 8, 9; Moine et al. 2005: Figs. 8, 9, 11). In result, the following further observations are supported:

4. The lymnaeid-planorbid relation is significant to discriminate the three clusters observed from sample size (Fig. 12a).

5. The abundance relationship between terrestrial and planorbid snails is equally characteristic for the three clusters, too (Fig. 12b).

Qualitatively and/or quantitatively, certain gastropod species are restricted to one or more of the observed clusters:

6. Clausiliids make up the largest portion of terrestrial gastropod individuals of the samples (Table 2), which are present in all samples with between 2 and 53 individuals. Characteristically, clausiliid numbers and percentages are especially high in samples I-III and in general rather low in samples VII-IX (Table 2).

7. The genus Granaria (two species) is restricted to samples I-III and VI. As these are the four smallest samples, the presence of this genus-although but present only in low individual numbers-must be considered a highly significant indicator for this cluster of samples.

8. The genus Gastrocopta is present with two species in samples VII-IX, 1onespecies in samples IV and V, and absent from samples I-III and VI. 

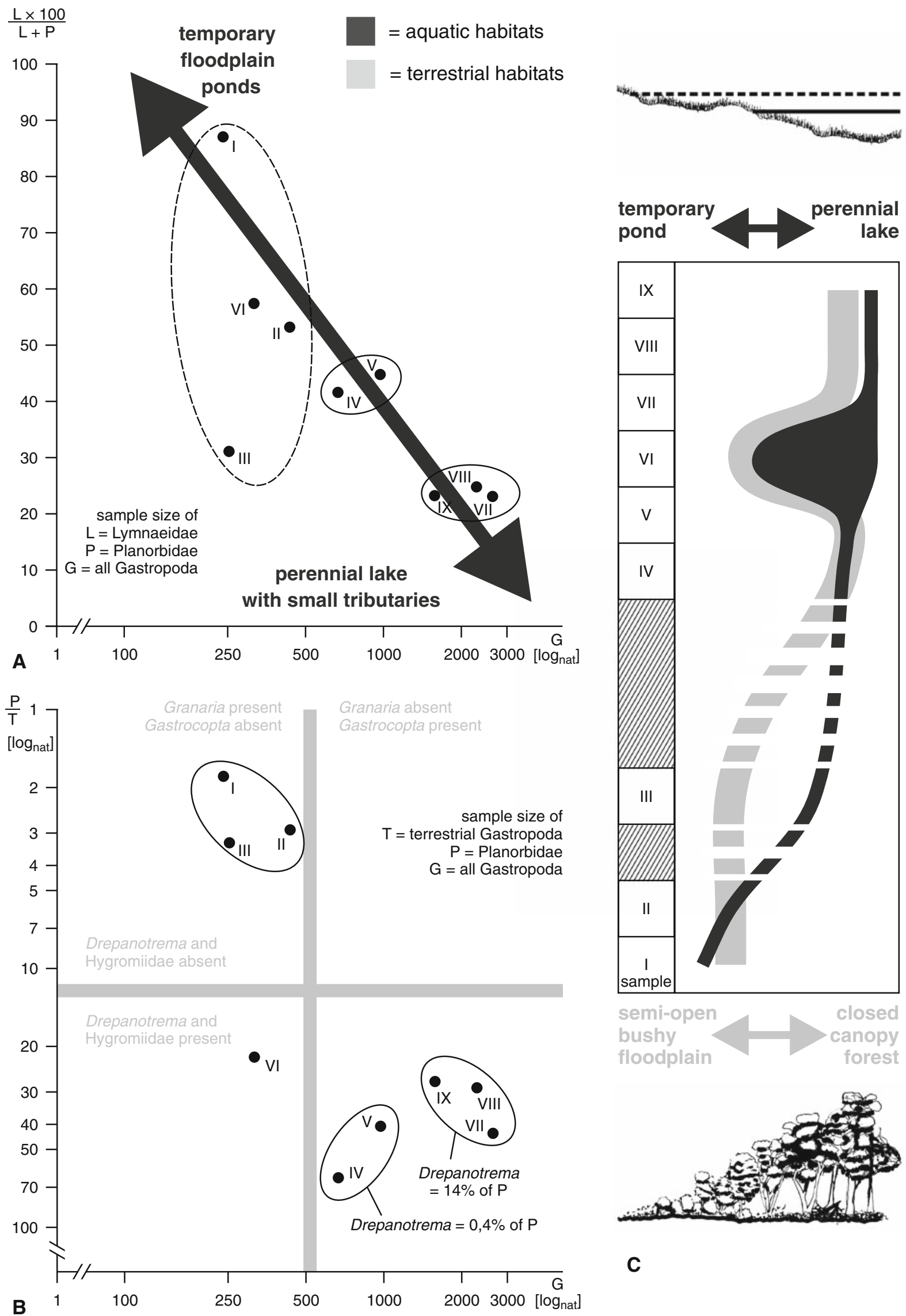

C 
9. The hygromiids (Trichiopsis, Hygromiidae spp. 1-3) are present with their highest diversity (at least two of four species represented) in samples VII-IX with rising abundance and occur only very rarely in the two other clusters (one specimen each in sample V and $\mathrm{VI})$.

10. Like the hygromiids, the vertiginids are most abundant in samples VII-IX (one species) and very rare in the two other clusters (one specimen each in samples III and V). However, Vertigo (two species) may have been present throughout the section, but is detected or not only by chance due to too small sample sizes.

11. All other terrestrial gastropods not mentioned above (6-10) are very rare and do not allow a meaningful interpretation with statistical methods. Predictably, the highest diversity (but not abundance) of terrestrial gastropods is observed for the largest samples (VII, VIII, and IX with 7, 10, and 8 species, respectively, and only 3-5 species in the smaller samples I-VI).

12. Planorbids show the highest diversity in samples VII, VIII, and IX (eight, nine, and ten species, respectively), intermediate diversity in samples IV and V (five and six species), and low diversity in samples I, II, III, and VI (three or four species). However, Segmentina and Hippeutis are rare species and only present in the largest samples, so for statistical reasons it may be assumed that they are present throughout the section.

13. The most abundant planorbids belong to Gyraulus and Menetus (Dilatata). In the small samples (I, II, III, and VI), the abundance relationship Gyraulus/ Menetus is between 3.0 and 3.4. In the large samples VIII and IX this value is slightly elevated to 3.7 and 4.1. In samples IV and VII the relationship is doubled to 6.4 and 6.5 , and in sample $\mathrm{V}$ there is a 10.5-fold dominance of Gyraulus over Menetus.

14. The genus Drepanotrema (2 species) is absent from samples I-III, and present, with rising abundances, in samples IV-VIII $(1,3,15,217,357$ specimens; or $0.1 \%, 0.3 \%, 4.7 \%, 8.2 \%, 15.6 \%$ of whole sample size), with a drop to 114 specimens $(6.7 \%$ of sample size) for the last sample IX.

Ecological interpretation of the changing abundance pattern in the quantitative samples

Four mollusc communities showing a characteristic distribution pattern in the three sample clusters can be distinguished compositionally:

- Community A of terrestrial gastropods is represented in samples I, II, III, and partially VI. It is characterized by dominating abundances of Clausiliidae, which indicate the presence of considerable amounts of ground litter with rotting wood in the surroundings of the Sandelzhausen pond, possibly in the aftermath of a wildfire event producing the lignitic layer $\mathrm{C} 2$. Community A is further characterized by the exclusive presence of Granaria, indicating a dry bushy floodplain landscape in the surroundings. Possibly Archaeozonites and/or Tropidomphalus belong also to this community, as these forms occur only as single specimens exclusively in the small samples I-III, VI, so if really rare, they would be expected to be absent from the fossil record. Thus, the lack of these forms in the larger samples of the community B is significant.

- Community B of terrestrial gastropods is represented in samples IV, V, VII, VIII, and IX. It is characterized by the presence of Hygromiidae div. sp. and Gastrocopta spp. and the lack of the community A indicator genus Granaria. Hygromiids and Gastrocopta are typical for closed-canopy forests with mossy ground litter.

- Community $\mathbf{C}$ of freshwater gastropods is most clearly represented in samples I and II, and partially in samples III and VI. Community C is dominated usually by the Lymnaeidae (I, II, VI), which show the presence of temporary (possibly dammed) water bodies in the vicinity, subject to occasionally longer drought periods probably affecting the Sandelzhausen pond itself. Planorbidae are present, but in low diversity (samples I to III, VI: 3-4 species each), and Drepanotrema, which is not drought tolerant, is completely absent in samples I-III.

- Community D of freshwater gastropods is most clearly represented in samples VII-IX, and to lesser degree in the intermediate samples IV and V. Community D is dominated by planorbids, which together imply the existence of a perennial lake with a network of (small) tributaries. Drepanotrema is the most discriminating component of this community in tolerating neither droughts nor swift water flows. The rising abundance of this genus shows the establishment of the perennial lake. Gyraulus, which is fond also of lotic conditions, is the most abundant form (around 50\% of whole mollusc fauna) and reacts most rapidly to changing ecological conditions-such as the stepwise establishment of the perennial lake with small tributaries-with peak abundances (samples IV + V, VII). Further support for the presence of a tributary system is seen in the unionids found in this stratigraphic level (Fig. 9).

Environmentally, the Sandelzhausen locality was situated within a floodplain and persisted as a sediment trap probably for at least several 100 or 1,000 years. Three sedimentological phases can be distinguished, the initial 
phase dominated by flooding events producing marls with high gravel content (layers A to C1), a second phase characterized by lignitic marls, possibly resulting from a wildfire event (layer $\mathrm{C} 2$ ), and a third phase, characterized by marls containing fewer coarse grains in a low-energy setting (beginning in layer C3). In general, layers with coarser grain sizes must be expected to contain an assortment of molluscs containing not only autochthonous and parautochthonous, but also allochthonous and even reworked elements, thus representing a wider range of habitats (Fahlbusch et al. 1972: 337). The mollusc fauna of the quantitative samples of Sandelzhausen allow to reconstruct a detailed history of the environmental conditions of that site:

At level I, the Sandelzhausen fossil site is situated in a floodplain and represents a large pond with several smaller, swampy temporary ponds in the surroundings; no fluvial network is established. Sedimentary influx containing allochthonous faunal elements is swept in occasionally, mainly by means of strong rain events rather than extensive floodings. Vegetation in the vicinity is of a semi-open type, i.e., dominated by bushy grasslands, as indicated by community A gastropods. Freshwater snails belong mainly to the drought-tolerant forms of community $\mathrm{C}$.

At levels II and III, a dramatic decrease of the lymnaeids indicates loss of temporary ponds from the surroundings. The hinterland becomes dry and is still covered only by semi-open thickets of scrub. Gastropoda belong to communities $\mathrm{A}$ and $\mathrm{C}$.

At level IV and V, the large Sandelzhausen pond evolves into a persistent lake, possibly via a rise in the water table. The freshwater snails respond with an increase of diversity and numbers of individuals, thus diminishing the percentage of terrestrial forms. The surroundings are now covered by humid, closed-canopy forests and a fluvial network is established. Mollusca now belong to communities $\mathrm{B}$ and $\mathrm{D}$.

At level VI, a short-term environmental fluctuation reestablishes the conditions of level II for the surroundings of the Sandelzhausen lake which, however, persisted rather unaffected. This is seen by a co-occurrence of mollusc communities A, C, and D. Alternatively, the mixture of communities could be seen as result of reworking.

At levels VI-IX, the Sandelzhausen lake is a large, perennial water body surrounded by an extensively forested hinterland with a small, steady fluvial network. The rich mollusc communities B and D are strongly established.

\section{Conclusions}

The following ecological interpretation is based on presence/absence and rough abundance data as published by
Gall (1972) and reinterpreted in this work (Table 1), and the quantitative analysis presented in this work (Table 2; Figs. 11, 12).

Derived from terrestrial gastropods, the more distant surroundings (allochthonous elements) of the Sandelzhausen pond contain forests with clearings and open or bushy grasslands and even exposed ground (calcareous gravels), all in a rather dry setting as testified by Pomatias, Granaria, Truncatellina, Vallonia, and possibly Palaeoglandina, Archaeozonites and Tropidomphalus. These elements typical for the open and dry habitats are rare in Sandelzhausen.

The closer vicinity (as indicated by higher abundances and diversity) of the Sandelzhausen pond contains damp to occasionally wet ground and humid forests with abundant litter and dead wood. Indicators for these conditions are Soosia, Gastrocopta, Cochlostoma, Carychium, Vertigo, Strobilops, Clausiliidae, ?Testacella, Lucilla, Discus, Patula, Vitrina, Hygromiidae, and Succineidae. Rather indifferent towards more dry or damp habitats are the limacids, milacids, and cepaeoids. Progressively, closedcanopy woodlands take over the semi-open bushy grasslands.

The freshwater molluscs show a clear tendency for an ecosystem evolution from temporary waters with low diversity and high drought tolerance (Lymnaeidae $>$ Planorbidae, large lymnaeids present) towards a stable, perennial lake with high diversity, high abundance (Planorbidae $>$ Lymnaeidae), drought-intolerant forms (Drepanotrema), and even forms adapted to the lotic conditions of perennial tributaries (Unionidae, Gyraulus). A special situation is recorded for layer $\mathrm{C} 2-\mathrm{C} 3$, where the large freshwater gastropods are predominantly represented by juvenile lymnaeids, indicating instable ecosystem relationships (temporary waters with longer drought periods).

Our ecological results are in agreement with and further enhance and substantiate interpretations derived from lower vertebrates (Böhme 1999, 2009 this volume), ostracods (Witt 1998), geochemistry (Tütken and Vennemann 2009 this volume), and sedimentology (Fahlbusch et al. 1972; M.M., unpublished data).

Acknowledgments We thank W. Werner and A. Nützel (Bayerische Staatssammlung für Paläontologie und Geologie, München) for access to material used in this work as well as V. Fahlbusch (Department für Geo- und Umweltwissenschaften, Universität München) and G. Rössner (Bayerische Staatssammlung für Paläontologie und Geologie, München) for suggesting this work and their encouragement. We are indebted to our reviewers W. Rähle (Tübingen), A. Nützel (München), M. Harzhauser (Wien), and M.L.D. Speight (Dublin), for their thorough work and valuable improvements. Participation of M.M. at the Sandelzhausen Symposium 2005 was made possible by grant of the DFG (GZ-4850/88/05). 


\section{Appendix 1}

Annotations to the mollusc fauna listed in Tables 1 and 2. The systematic arrangement follows the CLECOM-project (Falkner et al. 2001; Bank et al. 2001).

\section{GASTROPODA}

\section{NERITIDAE}

1. Neritina sp. A single shell found in one of the quantitative samples is interpreted as reworked.

2. Theodoxus sp. See Gall (1972: Nr. 51). The fragmentary shells show a weak color pattern.

\section{COCHLOSTOMATIDAE}

3. Cochlostoma sp. The genus is reported from Sandelzhausen for the first time; it is found in one quantitative sample and in old samples labeled "Grube Bergmaier."

POMATIIDAE.

4. Pomatias sp. See Gall (1972: Nr. 47).

BITHYNIIDAE.

5. Bithynia sp. A fragmentary shell and 13 opercula mentioned by Gall (1972: Nr. 48 \& 49) as "Bithynia glabra glabra (Zieten)" and "Bithynia sp." undoubtedly belong to this genus.

\section{HYDROBIIDAE.}

6. Belgrandiella sp. A single specimen found in a sample labeled "Grube Bergmaier" is interpreted as belonging to the Pleistocene period in the history of the site, when cryoturbations allowed for a deep invasion into older sediments (M.M., unpublished field observations).

VALVATIDAE.

7. Valvata (Cincinna) sp. See Gall (1972: Nr. 50) as "Valvata (Cincinna) cf. radiatula radiatula Sandberger" (Sandberger 1872: pl. 30, Fig. 7-7c; 1875: 576).

LYMNAEIDAE.

8. Galba sp. The material determined by Gall (1972: Nr. 37) as "Galba (Galba) subtruncatula (Clessin)" consists of juvenile shells from other lymnaeids and does not belong to this genus. However, in the quantitative samples a 'true' Galba is represented by one specimen.

9. Stagnicola sp./Omphiscola sp. This group of Lymnaeidae is recognized for the first time as a part of the Sandelzhausen fauna. Previously Gall (1972: Nr. 33, 36) identified these specimens partially as "Lymnaea turrita (Klein)" and "Radix (Radix) socialis praelongata (Gottschick and Wenz)"; additional material is found in "Grube Bergmaier" samples and the quantitative samples. The recent species of this group can be distinguished usually only by anatomical dissection; however, some of the fossil shells can be clearly attributed to one or other of these two genera.

10. Radix sp. (Fig. 3b-d). This is the most common lymnaeid species in Sandelzhausen and shows a high degree of variability. Previously, some of the material was determined by Gall (1972: Nr. 33, 34, 35, 36 and 37) as "Lymnaea turrita (Klein)" part., "Radix (Radix) socialis socialis (Zieten)", "Radix (Radix) socialis dilatata (Noulet)" part., "Radix (Radix) socialis praelongata (Gottschick \& Wenz)", and "Galba (Galba) subtruncatula (Clessin)" part. (See text for discussion of the influence of different preservation modes on taxonomic evaluation.)

11. Lymnaea sp. (Fig. 3a). Among the shells attributed by Gall (1972: Nr. 35) to "Radix (Radix) socialis dilatata (Noulet)" are a few that show the typical microsculpture and habitus of Lymnaea s. str., which is also found in quantitative samples.

12. Lymnaeidae indet. (Fig. 3e). The majority of small fragments, juvenile specimens or big deformed shells defy determination closer than Lymnaeidae indet., including many shells determined by Gall $(1972,1973)$ to subspecies level.

PLANORBIDAE.

13. Planorbarius sp. (Figs. 4, 5a-d). Despite difficulties due to preservation two morphs can clearly be distinguished among the adult shells, one more involute and thick, the other evolute and thin. These were already recognized by Gall (1972: Nr. 38 and 39) and determined as "Planorbarius cornu mantelli (Dunker)" and "Planorbarius cf. sansaniensis (Noulet)". However, a large number of inner whorls from all quantitative samples made us aware of a remarkably large variability, including all transitions (see Fig. 5a-d from one sample). It is suggested that these quantitative samples be tested morphometrically, to establish whether this observed variability is the result of a speciation process in progress, starting out from one lineage similar to that documented for Gyraulus and known for other freshwater molluscs from Steinheim (Sandberger 1874; Mensink et al. 1984; Nützel and Bandel 1993).

14. Menetus (Dilatata) albertanus (Clessin) (1877: 4041). In redescribing the fossil species Planorbis albertanus, Clessin (1885: 92-93, pl. 7, Fig. 1) hypothesized that it could be an antecendent to the recent species Planorbis dilatatus Gould of North America and its fossil relatives, for which he created the subgenus Planorbis (Dilatata). When Baker (1945: 187) described his new subgenus Menetus (Micromenetus) to receive the same type species, he was not aware of Menetus (Dilatata) of Clessin. Therefore Menetus (Micromenetus) is a junior objective synonym of Menetus (Dilatata). In Sandelzhausen two different morphs exist, the typical Menetus (Dilatata) albertanus, reported already by Gall (1972: Nr. 40), and a thicker form Menetus (Dilatata) sp., which, even in smallest inner whorls, can be distinguished clearly from Menetus (Dilatata) albertanus. Both biospecies are abundantly present in the quantitative samples.

15. Menetus (Dilatata) sp. See annotation 14 above.

16. Drepanotrema sp. 1. The genus Drepanotrema has not been recognized in the European Neogene fauna previously. Apart from specimens found in the quantitative samples, several individuals were subsumed by Gall (1972: 
Nr. 41, 42, 43) under "Gyraulus (Gyraulus) cf. goussardianus (Noulet)" part., "Gyraulus (Gyraulus) trochiformis ludovici (Noulet)" part., and "Gyraulus (Gyraulus) trochiformis kleini (Gottschick \& Wenz)" part. When compared with shells of the recent Drepanotrema cultratum complex, the forms from Sandelzhausen show considerable agreement. In his earlier publication Hubendick (1955) treated Fossulorbis (with the type species cultratum) as a separate genus. Later in his anatomical revision, Hubendick (1961, Hubendick in Harry \& Hubendick 1964) withdrew the separation and handled Fossulorbis as a subgenus, which is state of the art up to now. Herein we can only make a provisional attribution to the genus level. Drepanotrema sp. 1 is the most common species of the genus in the quantitative samples from Sandelzhausen. The specimens show ecologically influenced irregular growth, documented by pseudoribs.

17. Drepanotrema sp. 2. Only represented by material from the quantitative samples, this species is Anisus-convergent and rarer than Drepanotrema sp. 1 (see above).

18. Gyraulus sp. 1. This is the most common species of the genus in the quantitative samples from Sandelzhausen and highly variable. Without doubt, this species belongs to the so-called kleini group, reported already by Gall (1972: Nr. 43) as "Gyraulus (Gyraulus) trochiformis kleini (Gottschick \& Wenz) part., also including specimens erroneously determined by Gall (1972: Nr. 41, 42) as "Gyraulus (Gyraulus) cf. goussardianus (Noulet)" part. and "Gyraulus (Gyraulus) trochiformis ludovici (Noulet)" part.

19. Gyraulus sp. 2. This second species of Gyraulus is clearly outside of the variability of Gyraulus sp. 1 and quite rare and only known in the quantitative samples from Sandelzhausen.

20. Gyraulus sp. nov. Represented only in the quantitative samples, this species is unknown up to now in the Tertiary fauna of Europe and shows an albus-like sculpture.

21. Hippeutis sp. Specimens from quantitative samples, and those reported by Gall (1972: Nr. 44) as "Hippeutis subfontanus subfontanus (Clessin)", belong to Hippeutis, but are not identical with the Clessin species (Clessin 1877: 39-40; 1885: 91-92, pl. 7 Fig. 4).

22. Segmentina sp. (Fig. 5e). See Gall (1972: Nr. 45) as "Segmentina larteti larteti (Noulet)"; also present in quantitative samples.

23. ?Ancylus sp. nov. This material has been attributed by Gall (1972: Nr. 46) to "Ancylus deperditus cf. deperditus (Desmarest)"; however, up to now it is unclear whether this species belongs Ferrissia or Ancylus.

24. Planorbidae indet. Fragmentary and deformed material.

CARYCHIIDAE.

25. Carychium sp. 1 (broad form). See Gall (1972: Nr. 32) as "Carychium nouleti gibbum Sandberger"
(Sandberger 1875: 583). Like recent Carychium tridentatum and Carychium minimum in Middle Europe there exist two syntopical species with different habitus in Sandelzhausen.

26. Carychium sp. 2 (elongate form). See Gall (1972: Nr. 31) as "Carychium nouleti nouleti Bourguignat"] and annotation above.

27. Carychium sp. 3 (eumicron-complex). See Gall (1972: Nr. 30) as "Carychium eumicron peneckei Flach". The eumicron group has a long stratigraphic record.

SUCCINEIDAE.

28. Succineidae (gen. et sp. indet.). In a sample labeled "Grube Bergmaier." The family is reported for the first time from Sandelzhausen.

STROBILOPSIDAE.

29. Strobilops (Strobilops) sp. nov. Among those specimens determined by Gall (1972: Nr. 10) as "Discus pleuradra pleuradra (Bourguignat)" one shell belongs to Strobilops s. str. On the upper side the ribs are fine, sharp, and closely spaced, which has not been reported from any species of the European Tertiary. The figure of Strobilops subconoideus Jooss 1912 (pp 34-35, pl. 2, Fig. 4; reproduced by Wenz 1915: pl. 4, Fig. 3) is suggestive of a similar ribbing; however, in description Jooss (1912: 35) mentioned these as "äusserst feine Anwachsstreifen" [extremely fine growth stripes]. Further on, S. subconoideus is compared to $S$. boettgeri (Andreae 1902: 10, Fig. 5) from Oppeln (Opole), which shows a strongly departing habitus and belongs to an evolutionary line, which merits subgeneric status.

30. Strobilops (Discostrobilops) sp. Among those specimens determined by Gall (1972: Nr. 10) as "Discus pleuradra pleuradra (Bourguignat)" four shells turned out to belong to Strobilops Pilsbry 1893, Subgenus Discostrobilops Pilsbry 1927. These are distinguished on the upper side by strong and sharp ribs similar to, but clearly more developed than, those in S. (Discostrobilops) uniplicatus (Braun 1851), which is also distinguished by a more highly elevated apex. These characters point possibly towards the forgotten Strobilus diezi Clessin (1912: 104), which, however, according to its original description, is only moderately strong ribbed.

VALLONIDAE.

31. Vallonia lepida (Reuss). See Gall (1972: Nr. 24) as "Vallonia subpulchella subpulchella (Sandberger)" (Sandberger 1872: pl. 29 Fig. 3-3c, 1875: 544-545). For a long time the name subpulchella of Sandberger-erroneously coined-has been used uncritically. Recently, however, Gerber (1996: 96) recognized Vallonia lepida (Reuss) as an older synonym. Stratigraphically Vallonia lepida is a long-standing form reaching from middle Oligocene to the early Pliocene and is possibly antecedent to the recent Vallonia pulchella. 


\section{CHONDRINIDAE.}

32. Granaria sp. 1. (Fig. 6i). See Gall (1972: Nr. 29) as "Napaeus? sp." part.

33. Granaria sp. 2. See Gall (1972: Nr. 29) as "Napaeus ? sp." part.

VERTIGINIDAE.

34. Truncatellina sp. See Gall (1972: Nr. 28) as "Pyramidula subteres (Clessin)" (See annotation 44 for Lucilla subteres).

35. Vertigo (Vertigo) callosa (Reuss). See Gall (1972: Nr. 27) as "Vertigo (Vertigo) callosa cardiostoma (Sandberger)" (Sandberger 1875: 600).

36. Vertigo $\mathrm{sp}$.

GASTROCOPTIDAE.

37. Gastrocopta (Albinula) acuminata (Klein). See Gall (1972: Nr. 25) as "Gastrocopta (Albinula) acuminata acuminata (Klein)".

38. Gastrocopta (Sinalbinula) nouletiana (Dupuy). (Fig. 6g). See Gall (1972: Nr. 26) as "Gastrocopta (Sinalbinula) nouletiana nouletiana (Dupuy)".

CHONDRINIDAE/ENIDAE.

39. ?Chondrinidae/?Enidae (fam., gen. et sp. indet.). See

Gall (1972: Nr. 29) as "Napaeus ? sp." part.

CLAUSILIIDAE.

40. Clausiliidae gen. indet. sp. 1 (big, broad form). Only in one quantitative sample.

41. Clausiliidae gen. indet. sp. 2. See Gall (1972: Nr. $22)$ as "Pseudidyla moersingensis zandtensis (Boettger)". Abundant in quantitative samples.

TESTACELLIDAE.

42. Testacella sp. See Gall (1972: Nr. 3) as "Testacella larteti larteti Dupuy". The shell of Testacella lartetii Dupuy 1850 (correct original spelling) from Sansan is clearly flatter than the diagnostic fragmentary shell from Sandelzhausen, which by its steep external apertural wall gains remarkable deepness. In contrast to the ascertion of Gall (1972: 7) it is found in an even more strongly developed condition, in which the apertural margin builds nearly a right angle with the apertural wall. In comparison with the figure in Dupuy (1850: pl. 15, Fig. 2a-d) the Sandelzhausen specimen shows a broadly developed, more strongly indented columellar lip, broadly taken off in the upper part. Therefore an attribution to $T$. lartetii seems questionable.

OLEACINIDAE.

43. Palaeoglandina sp. (Fig. 6c, d). See Gall (1972: Nr. $23)$ as "Palaeoglandina gracilis porrecta (Gobanz)".

\section{HELICODISCIDAE.}

44. Lucilla sp. nov. Among those specimens determined by Gall (1972: Nr. 10) as "Discus (Discus) pleuradra pleuradra (Bourguignat) one can be attributed unambiguously to the genus Lucilla. Lucilla subteres was erected by Clessin (1877: 35) as Helix (Patula) subteres, later transferred to Pyramidula by Wenz (1923: 1062-1063) and to
Helicodiscus, subgenus Hebetodiscus, by Falkner (in Schlickum 1976: 12), which latter subgenus is now generally accepted as a younger synonym of Lucilla. Compared with Lucilla subteres from Undorf (Clessin 1885: 76, pl. 7 Fig. 6), the Lucilla from Sandelzhausen possesses a clearly flatter spire and a generally more delicate appearance; however, the coiling proceeds more swiftly.

DISCIDAE.

45. Discus cf. pleuradrus (Bourguignat). (Fig. 6j). Only one deformed juvenile, of the ten specimens determined by Gall (1972: Nr. 10) as "Discus (Discus) pleuradra pleuradra (Bourguignat)" [sic], can be unambiguously attributed to Discus. The spelling "pleuradra" used by Gall (1972) and Schlickum (1976) is incorrect as the word is a latinized adjective (gr. pleura $=$ side, rib; gr. hadros = strong), which must be declined in accordance with the gender of the genus with which it is combined.

An adult conspecific specimen from the quantitative samples of Sandelzhausen agrees well with material from Zwiefaltendorf (cf. Schlickum 1976: pl. 2, Fig. 37). Schlickum raised doubts that stratigraphically younger material (younger than Tortonian) can be attributed to this species. This is corroborated by comparison to specimens figured by Harzhauser and Binder (2004: pl. 7, Figs. 9-11), which represent an obviously related but different species. The mandatory comparison with material from Sansan has not yet been conducted, therefore the specimens from Sandelzhausen are only provisionally attributed to Discus cf. pleuradrus.

46. ? Discidae (fam., gen. et sp. indet.). A strongly ribbed whorl fragment has been attributed by Gall (1972: Nr. 10) to "Discus (Discus) pleuradra pleuradra (Bourguignat)" [sic]. However, due to the different whorl section outline (strongly indented suture, steep umbilical wall) it cannot be attributed to the genus Discus.

ENDODONTIDAE.

47. ? Endodontidae sp. nov. (fam. et gen. indet.). Two juvenile or fragmentary spires, again referred by Gall (1972: No. 10) to "Discus (Discus) pleuradra pleuradra (Bourguignat)" [sic], are characterized by a high whorl section outline, tight whorls, flat spire, and a drill-hole-like umbilicus. They belong to a previously unknown endodontid type, which strongly resembles recent tropical forms.

48. ? Endodontidae gen. nov. (fam. et gen. indet.). (Fig. 6f). See Gall (1972: No. 6) as "Zonitoides silvanus Wenz". The attribution of this rather shattered and deformed shell to the species appears to be correct; however, an affiliation of this form to the genus Zonitoides is excludable. The development of the protoconch and the shape of the abapical side both suggest a hitherto unknown endodontid genus.

GASTRODONTIDAE.

49. Janulus cf. supracostatus (Sandberger). (Fig. 6h). See Gall (1972: Nr. 7) as "Janulus cf. supracostatus 
(Sandberger)". The name Patula supracostata first became available from 1872 (Sandberger 1870-1875, installment 6-8), in the explanation of plate 29, Fig. 2-2c, while the accompanying description was published only in 1875 ("Schlussheft": p 584, for revised publication dates see Appendix 2). Therefore, the plate has priority over the text and the figured specimen is the holotype. Wenz (1923: 304) asserted that figure and diagnosis relate to two different species. However, his practice of tying the name supracostata with the later published diagnosis is not permissible. This is also the case for the use of the name by Schlickum (1976: 23) and Harzhauser and Binder (2004: 131), who cite "1874", the assumed year publication of the diagnosis (actually this should read 1875, see Appendix 2). The name supracostata cannot be attributed to a real taxon as long as the generic identity of the figured specimen is unclear. Contrary to the opinion of Wenz (1923: 305) it is not a Gonyodiscus, but probably belongs to the "Discus-convergent" Janulus germainae group (Niederhöfer and Falkner 2004: 158). The specimens figured by Schlickum (1976: pl. 3, Figs. 43, 44) as Janulus supracostatus and Janulus moersingensis Jooss 1918 likewise belong to this group, which probably represents an independent phylogenetic unit not linked to the evolutionary lineage characterized by the taxa Patula gyrorbis Klein sensu Sandberger (1872: pl. 21, Fig. 7) and Janulus austriacus Harzhauser and Binder 2004 (p 131, pl. 7, Figs. 12-15).

\section{ZONITIDAE.}

50. Archaeozonites sp. (Fig. 6a). See Gall (1972: Nr. 5) as "Archaeozonites costatus costatus Sandberger" (Sandberger 1875: 604). According to Lueger (1981) the status and relationships of this species are unclear.

\section{MILACIDAE.}

51. Milax sp. The attribution of the reference material to "Limax sp." part. by Gall (1972: No. 8) is incomprehensible, because the small shells show an asymmetrical bauplan with an excentric nucleus. The material contains more than one biospecies (see no. 53 Limax below), suggestive of a high slug biodiversity, as has been described for Undorf (Clessin 1912: 112) or Oppeln [Opole] (Andreae 1904: 3-5).

\section{VITRINIDAE.}

52. Vitrina sp. nov. Gall (1972: No. 4) doubtfully attributed material to "Vitrina cf. suevica suevica Sandberger" (Sandberger 1872: pl. 29, Figs. 27-27b; 1875: $602)$, probably assuming that the taxon described from Steinheim belongs to true Vitrina in a modern sense. However, Wenz (1923: 216), defined the genus Vitrina by the type species Vitrina major (Draparnaud 1801), which corresponds to the recent genus Phenacolimax (see also Hesse 1923: 3, 97). Contrary to the depressed Phenacolimax-like shells of the conchological group of Vitrina suevica, the specimens from Sandelzhausen indeed show a more spherical shape associatable with Vitrina sensu stricto.

LIMACIDAE.

53. Limax spp. See Gall (1972: No. 8, 9) as "Limax sp." part. and "Milax sp.". The material attributed by Gall to Limax contains several species belonging to different genera. Besides true Limax, there are rudimentary shells with a central nucleus which belong, according to current understanding, to the Milacidae (see no. 51 Milax sp.). Whereas early named limacid finds ("Limax" crassitesta Reuss 1868, “Limax" lingulatus Sandberger 1875) belong to the Limacus group (Sandberger 1875: 603), the Sandelzhausen shells do represent true Limax and possibly the oldest record of this genus.

ELONIDAE.

54. Soosia (Prosoosia) cf. godarti Michaud. (Fig. 6b). See Gall (1972: No. 18) as "Klikia (Klikia) giengensis giengensis (Klein)". The shell from Sandelzhausen has been compared with the holotype of Helix giengensis Klein 1846 (SMNS IMDAS-No. 25271/2005) from Hohenmemmingen. It turned out that the type possesses more voluminous whorls, a steeper last whorl, coarser ribs, a wider umbilicus, a higher spire, more pronounced hair knobs, an apertural lib with strongly projecting callus in the umbilical area, and a less pronounced quincunx texture than the specimen from Sandelzhausen. The latter matches well with the figure of Helix godarti Michaud sensu Sandberger (1872: pl. 27, Fig. 16).

Nordsieck (1986: 118) fixed Helix godarti Michaud as type species of his new subgenus Soosia (Prosoosia) and follows so far Schlickum and Strauch (1970: 165), who had studied the type of godarti and referred it to the genus Soosia for the first time. Our investigations confirm a complete concordance of the quincunx microtexture of the specimen from Sandelzhausen with that of recent shells of the living Soosia diodonta (Férussac) from Serbia and Romania.

55. Soosia sp. indet. A partially compressed shell already seen by Gall (1972: No. 17, as "Klikia (Apula) sp.") is larger and substantially flatter than those of the previous species. It shows a clear quincuncial microtexture, which is also seen in a comparable spire whorl fragment from the quantitative samples. An attribution to the subgenus Prosoosia is dispensed here.

? ELONIDAE.

56. Tropidomphalus (Pseudochlorites) sp. (Fig. 7). See text on preservation and taxonomy of material attributed by Gall (1972: No. 13-16) to "Tropidomphalus (Pseudochloritis) extinctus (Rambur), "Tropidomphalus (Pseudochloritis) incrassatus incrassatus (Klein)", "Tropidomphalus (Pseudochloritis) zelli (Kurr)", and "Tropidomphalus ? sp." 


\section{HELICODONTIDAE.}

57. ? Protodrepanostoma sp. See Gall (1972: No. 12) as "Helicodonta (Helicodonta) involuta scabiosa (Sandberger)" [Sandberger 1875: 584-585]. Specimen not found in collection. The species awaits revision, for the moment it is unclear whether it belongs to Protodrepanostoma (see Falkner 1986) or Helicodonta (see remarks by Manganelli and Giusti 2000).

58. ? Helicodontidae (fam., gen. et sp. indet.) 1. Found in quantitative sample.

59. ? Helicodontidae (fam., gen. et sp. indet.) 2. Found in quantitative sample.

\section{HYGROMIIDAE.}

60. Trichiopsis sp. (Fig. 6e]. See Gall (1972: No. 11) as "Leucochroopsis kleini kleini (Klein)" [sic] part. Of Gall's three specimens, two, a steinkern and a juvenile specimen, can be associated with what is usually understood as Leucochroopsis kleinii. Additional conspecific specimens were found in the quantitative samples. These Sandelzhausen specimens correspond generically to comparative material from Hohenmemmingen (type locality of Helix kleinii Klein 1846) and Mörsingen, but differ further from the already per se slightly different occurrences (Gottschick and Wenz 1916: 31), by a clear character leap, encompassing a substantially more spacious and coarser development of hair scars as well as a differing shape of the protoconch and stronger edged whorls. The type species of Leucochroopsis is Leucochroa (Leucochroopsis) emmerichi Boettger 1908, from Budenheim. Concerning the diagnosis of this species the references contain a curious contradiction which to our knowledge has not been resolved. In description of species and subgenus Boettger (1908: 148) emphasized the "Mangel jeder Art von Mikroskulptur" [lack of any kind of microsculpture] as decisive diagnostic feature, while Zilch (1960: 684), who for the first time figured the species, extensively described a fine sculpture of "äußerst feinen Spiralstreifen, mit regelmäßig in Schrägzeilen angeordneten rundlichen oder etwas gestreckten Haargrübchen bzw. -papillen" [exceedingly fine spiral stripes with rounded or slightly elongated hair pits or papillae which are regularly spaced in oblique rows]. The attribution of the different stratigraphically wide-spanning occurrences of "Leucochroopsis kleini" of authors, as well as the attribution of further species to this genus, appears to be questionable requires urgent reappraisal.

61. Hygromiidae gen. indet. sp. 1. Not umbilicated. Previously not recognized in Sandelzhausen.

62. Hygromiidae gen. indet. sp. 2. Umbilicated. Previously not recognized in Sandelzhausen.

63. Hygromiidae gen. indet. sp. 3. Basally with threads. The third specimen attributed by Gall (1972: No. 11) to "Leucochroopsis kleini kleini (Klein)" is a markedly distinct hygromiid type also found in the quantitative samples.
HELICIDAE.

64. "Cepaea" sp. 1. (Fig. 8j). See Gall (1972: No. 20, 21) as "Cepaea eversa larteti (Boissy)" and "Cepaea silvana silvana (Klein)" part.

65. "Cepaea" sp. 2. (Fig. 8m-p]. See Gall (1972: No. 21 and 19) as "Cepaea silvana silvana (Klein) part. and "Hemicycla asperula cf. leymerieana (Noulet)".

66. "Cepaea" sp. indet. (Fig. 8k-1). Mostly fragmentary and deformed helicid material. Attribution to "Cepaea" is meant to indicate a roughly Cepaea-like morphology; comparison with other "species" and "genera" from, e.g., the French Miocene will be necessary (e.g., Truc 1971a,b) See also text for erroneous taxonomy related to problematical preservation.

BIVALVIA.

UNIONIDAE.

67. Unionidae gen. indet. sp. nov. (Fig. 9). Previously unknown from Sandelzhausen. The species is characterized by its small size, rather strong shell, and strong hinge, combined with a roughly parallelogram-like outline. Very conspicuous characters are the strongly developed elongated and flattened cardinal tooth in the right valve, combined with an interrupted hingeplate between cardinal and lateral tooth (interval). These latter characters exclude an attribution to the genus Unio to which the specimen resembles at first glance. Nothing similar has up to now been recorded from north-alpine Molasse sites. The generic allocation still needs extensive comparisons which at the moment can not be achieved. The Lebensformtyp indicates a more lotic biotope with rather coarse bottom. Thus a short distance transport of the articulated valves to a marly (more lentic) embedding site can be assumed.

SPHAERIIDAE.

68. Sphaerium sp. See Gall (1972: No. 1).

69. Pisidium sp. See Gall (1972: No. 2).

\section{Appendix 2}

Revised publication dates for Sandberger, Die Land- und Süsswasser-Conchylien der Vorwelt, 1870-1875.

According to Wenz (1923: 163), the parts of this monograph were published as follows:

\begin{tabular}{lccl}
\hline Instalment & Pages & Plates & Publication date \\
\hline $1-3$ & $1-96$ & $1-12$ & 1870 \\
$4-5$ & $97-160$ & $13-20$ & 1871 \\
$6-8$ & $161-256$ & $21-32$ & 1872 \\
$9-10$ & $257-352$ & $33-36$ & 1873 \\
11 & $353-616$ & - & 1874 \\
12 & $617-1000$ & - & 1875 \\
\hline
\end{tabular}


According to Woodward (1906: 3-4), however, the 11th part contained the total remaining pages $353-1,000$ and was published in 1875 (parts 1-10 and their publication dates are listed identically). Woodward obtained the publication dates of Sandbergers' monograph through correspondence with the original publisher, noting that no bibliographer had given the contents of the work except for Dollfus and Ramond (1886), "(Bibliographie de la Conchyliologie du Terrain Tertiaire Parisien", p 20), who inaccurately "attribute 12 parts instead of 11". It appears that Wenz (1923) in his catalogue did copy from the latter source and not from Woodward (1906).

However, the publication dates can be verified contra Woodward by several bibliographical sources, which carefully recorded the contents and dates of the several parts. Once more, the most useful source for dating palaeontological works of the 19th century is the Neues Jahrbuch für Mineralogie, Geologie und Paläontologie (published under various titles from 1807 till now). There, usually, first a note citing the work and publication details is printed on receipt (tabulated below under letter $\mathrm{D}=$ date), followed a few months later by publication of a short review or excerpt (see under $\mathrm{R}=$ review). Furthermore, the Geological Society of London recorded donations to the library in their proceedings (Quarterly Journal of the Geological Society), providing independent confirmation. According to these sources, the dates given by Woodward (1906) and Wenz (1923) require to be modified as follows:

Sandberger, C.[Carl] L.[Ludwig] Fridolin (1870-1875): Die Land- und Süsswasser-Conchylien der Vorwelt.viii +1000 pp., 1 tab., 36 pls.; Wiesbaden (C. W. Kreidel).

\begin{tabular}{llcccccc}
\hline $\begin{array}{l}\text { Part/ } \\
\text { Lieferung }\end{array}$ & pp. & $\begin{array}{l}\text { pls./ } \\
\text { tab. }\end{array}$ & $\begin{array}{l}\text { Date } \\
\text { NJb }\end{array}$ & $\begin{array}{l}\text { NJb } \\
\text { (R) }\end{array}$ & QJGS & Notes \\
\hline 1 & $1-32$ & $1-4$ & 1870 & 1870 & $1870(8):$ & 1871,27 & 1 \\
& & & & $(6):$ & 1014 & {$[2]:$} & \\
& & & & 771 & & 184 & \\
$2+3$ & $33-96$ & $5-12$ & 1870 & 1871 & $1871(5):$ & 1871,27 & \\
& & & & $(5):$ & $558-$ & {$[4]:$} & \\
& & & & 504 & 559 & 563 & \\
$4+5$ & $97-160$ & $13-20$ & 1871 & 1872 & $1872(7):$ & 1872,28 & 2 \\
& & & & $(2):$ & $776-$ & {$[3]:$} & \\
& & & & 211 & 777 & 379 & \\
$6+7+8$ & $161-256$ & $21-32$ & 1872 & 1873 & $1873(7):$ & 1873,29 & \\
& & & & $(2):$ & 777 & {$[3]:$} & \\
& & & & 175 & & 491 & \\
$9+10$ & $257-352$ & $33-36$ & 1873 & 1873 & $1874(1):$ & 1874,30 & 3 \\
& & & & $(6):$ & $103-$ & {$[\mathrm{P}]:$} & \\
& & & & 632 & 104 & cxxix & \\
\multirow{5}{*}{ Schlussheft } & [i-viii], & 1 tab. & 1875 & 1876 & $1876(5):$ & 1876,32 & 4 \\
& $353-$ & & & $(2):$ & $571-$ & {$[\mathrm{P}]:$} & \\
& 1,000 & & & 187 & 572 & 205 & \\
\hline
\end{tabular}

Notes

1: Additional proof for separate publication of part 1 (Lieferung 1) is found in J. C. Hinrichs (1871: Hinrichs fünfjähriger Bücher-Catalog, 4, ed. A. Büchting, p. 317); see also note 3 . Although not expressly stated as such, the two donations by Sandberger to the library of the Geological Society of London recorded in the Quarterly Journal, are also taken as evidence for separate publication of parts 1 and $2+3$.

2: In a letter to the editor of Neues Jahrbuch dated 16.11.1871, Sandberger (1872: Neues Jahrbuch etc., 1872 (1), pp 73-76) himself announced instalments 4 and 5 soon to be published, and he mentioned that he had finished all of the 36 plates to accompany the work.

3: According to W. Heinsius (1878: Allgemeines Bücher-Lexikon, 15 (2), ed. H. Ziegenbalg, p. 469), the parts 1-10 consisted of pp. 1-352, 36 pls., and were published 1870-1874. This is the only hint for parts of the work being published in 1874 , but this is discarded in favor of the more contemporaneously published evidence in Neues Jahrbuch etc. and Quarterly Journal etc.-According to J. C. Hinrichs (1881: Hinrichs fünfjähriger BücherCatalog, 5, ed. R. Haupt, p. 426), the parts 2-10 consisted of pp. 33-352, 22 pls., published 1872. These details can hardly be considered accurate, but they show a separate publication of parts 1 and $2+3$ (see note 1 ).

4: The final part is not termed "Lieferung 11" but "Schlussheft". This term is found in all ciations in Neues Jahrbuch etc. and the Quarterly Journal etc., as well as in W. Heinsius (1882: Allgemeines Bücher-Lexikon, 16 (2), ed. O. Kistner, p 399); in J. C. Hinrichs (1881: Hinrichs fünfjähriger Bücher-Catalog, 6, ed. R. Haupt, p 535); and in C. G. Kayser (1877: Index locupletissimus librorum etc. $=$ Vollständiges Bücher-Lexicon etc., 20, ed. R. Haupt, p 389). The final part also contained 8 pages preceding the work (i-viii) in which the preface is dated 15 October 1875 .

\section{References}

Albesa, J., J.P. Calvo, L. Alcalá, and A.M. Alonso Zarza. 1997. Interpretación paleoambiental del yacimiento de La Gloria 4 (Plioceno, Fosa de Teruel) a partir del análisis de facies y de asociaciones de gasterópodos y de mamíferos. Cuadernos de Geología Ibérica 22:239-264.

Andersson, K., and A. Kaakinen. 2004. Floodplain processes in the shaping of fossil bone assemblages: an example from the Late Miocene, Bahe Formation, Lantian, China. GFF 126(3):279_ 287.

Andreae, A. 1902. Zweiter Beitrag zur Binnenconchylienfauna des Miocäns von Oppeln in Schlesien. Mitteilungen aus dem Roemer-Museum, Hildesheim 18:1-31. 
Andreae, A. 1904. Dritter Beitrag zur Binnenconchylienfauna des Miocäns von Oppeln in Schlesien. [variant inner title: Dritter Beitrag zur Kenntnis des Miocäns von Oppeln i. Schl.]. Mitteilungen aus dem Roemer-Museum, Hildesheim 20:1-22.

Baker, F.C. 1945. The molluscan family Planorbidae-xxxvi +530 , 141 pls., Urbana: University of Illinois Press.

Bank, R.A., P.H. Bouchet, G. Falkner, E. Gittenberger, B. Hausdorf, T. von Proschwitz, and Th.E.J. Ripken. 2001. Supraspecific classification of European non-marine Mollusca (CLECOM Sections I + II). Heldia 4(1/2):77-128.

Böhme, M. 1999. Die miozäne Fossil-Lagerstätte Sandelzhausen 16. Fisch- und Herpetofauna-Erste Ergebnisse. Neues Jahrbuch für Geologie und Paläontologie, Abhandlungen 214:487-495.

Böhme, M. 2009 this volume. Ectothermic vertebrates (Actinopterygii, Allocaudata, Urodela, Anura, Crocodylia, Squamata) from the Miocene of Sandelzhausen (Germany, Bavaria): their implication for environmental reconstruction and palaeoclimate. In: Fossil lagerstätte Sandelzhausen (Miocene, southern Germany): Contributions to the fauna, Paläontologische Zeitschrift, eds. Rössner, G.E. and Göhlich, U.B., 83(1):000-000.

Boettger, O. 1889. Die Entwicklung der Pupa-Arten des Mittelrheingebietes in Zeit und Raum. Jahrbuch des nassauischen Vereins für Naturkunde 42:225-327. [also published as separatum with pagination 1-103].

Boettger, O. 1908. Die fossilen Mollusken der Hydrobienkalke von Budenheim bei Mainz. Nachrichtsblatt der deutschen Malakozoologischen Gesellschaft 40(4):145-157.

Braun, A. 1851. In Die fossile Fauna des Mainzer Beckens. Wirbellose Thiere, 1112-1141 [or 28-57 in separate], ed. Walchner, F.A., In Darstellung der geologischen Verhältnisse des Mainzer Tertiärbeckens und seiner fossilen Fauna und Flora, ed. Walchner, F.A., Handbuch der Geognosie zum Gebrauche bei seinen Vorlesungen und zum Selbststudium mit besonderer Berücksichtigung der geognostischen Verhältnisse des Grossherzogthums Baden. [2nd ed., 1846-1851]: 1085-1159 [also published as separate with pagination 1-75], Karlsruhe (C. Th. Groos).

Bustillo, M.A., and A.M. Alonso-Zarza. 2007. Overlapping of pedogenesis and meteoric diagenesis in distal alluvial and shallow lacustrine deposits in the Madrid Miocene Basin, Spain. Sedimentary Geology 198(3/4):255-271.

Clessin, S. 1877. Die tertiären Binnenconchylien von Undorf. [I.]. Correspondenzblatt des mineralogisch-zoologischen Vereins zu Regensburg 31(3):34-41.

Clessin, S. 1885. Die Conchylien der Obermiocaenen Ablagerungen von Undorf. [II.] Malakozoologische Blätter, (N. F.) 7(2) [1884]: 71-95.

Clessin, S. 1912. Die Conchylien der obermiocaenen Ablagerung von Undorf. IV. Mitteilung. Berichte des naturwissenschaftlichen Vereines in Regensburg 13(1910-1911):101-114.

Davis, E.C., K.E. Perez, and D.J. Bennett. 2004. Euglandina rosea (Férussac, 1821) is found on the ground and in trees in Florida. Nautilus 118(3):127-128.

Dollfus, G., and G. Ramond. 1886. Bibliographie de la Conchyliologie du Terrain Tertiaire Parisien. 28, Rennes-Paris (Oberthur).

Dupuy, D. 1850. Description de quelques espèces de coquilles terrestres fossiles de Sansan. Journal de Conchyliologie 1(3): 300-313.

Emerson, W.K. and M.K. Jacobson. 1976. The American Museum of Natural History guide to shells . Land, freshwater, and marine, from Nova Scotia to Florida-482 + xviii pp., 47 pls., New York (A. A. Knopf).

Esu, D., and A. Ciangherotti. 2004. Palaeoecologic and palaeobiogeographic character of Middle Pliocene non-marine mollusc faunas from north-western Italy. Rivista Italiana di Paleontologia e Stratigrafia 110(2):517-530.
Fahlbusch, V. 1974. Aus Bayerns Tierwelt vor 15 Millionen Jahren . Ausgrabungen fossiler Säugetiere im Alpenvorland. Der Aufschluss 25(9):458-464.

Fahlbusch, V. 2003. Die miozäne Fossil-Lagerstätte Sandelzhausen. Die Ausgrabungen 1994-2001. Zitteliana, A 43:109-122.

Fahlbusch, V., and H. Gall. 1970. Die obermiozäne Fossil-Lagerstätte Sandelzhausen. 1. Entdeckung, Geologie, Faunenübersicht und Grabungsbericht. Mitteilungen der Bayerischen Staatssammlung für Paläontologie und historische Geologie 10:365-396.

Fahlbusch, V., H. Gall, and N. Schmidt-Kittler. 1972. Die obermiozäne Fossil-Lagerstätte Sandelzhausen. 2. Sediment und Fossilinhalt · Probleme der Genese und Ökologie. Neues Jahrbuch für Geologie und Paläontologie. Monatshefte 1972(6):331-343.

Falkner, G. 1986. Protodrepanostoma nordsiecki n. sp. aus dem untermiozänen Landschneckenkalk von Tuchorice/Böhmen (Gastropoda: Hygromiidae). Heldia 1(4):121-123.

Falkner, G. 1990. Binnenmollusken. In Steinbach, G., ed., Steinbachs Naturführer, [10], Weichtiere [Fechter, R. \& Falkner, G.]: 112 280, München (Mosaik).

Falkner, G. 1992. In Binnenschnecken - Süßwassermuscheln, eds. Reichholf, J.H. and Steinbach, G., Die grosse Bertelsmann Lexikothek Naturenzyklopädie Europas, 6, Mollusken und andere Wirbellose: 238-321, München (Mosaik).

Falkner, G., R.A. Bank, and T. von Proschwitz. 2001. Check-list of the non-marine molluscan species-group taxa of the states of northern, atlantic and central Europe (CLECOM I). Heldia $4(1 / 2): 1-76$

Fordinál, K. 1996. Terrestrial gastropods of the Upper Pannonian in the northern part of the Danube Basin. Slovak Geological Magazine 1(96):5-16.

Franzen, D.S., and A.B. Leonard. 1947. Fossil and living Pupillidae (Gastropoda-Pulmonata) in Kansas. University of Kansas Science Bulletin 31(2,15):311-411.

Galiana, R. 1979. Nuevos yacimientos malacologicos en el Terciario continental de Mallorca. Boletin de la Sociedad de Historia Natural de Baleares 23:117-126.

Gall, H. 1972. Die obermiozäne Fossil-Lagerstätte Sandelzhausen. 4. Die Molluskenfauna (Lamellibranchiata, Gastropoda) und ihre stratigraphische und ökologische Bedeutung. Mitteilungen der Bayerischen Staatssammlung für Paläontologie und historische Geologie 12:3-32.

Gall, H. 1973. Die obermiozäne Fossil-Lagerstätte Sandelzhausen. 8. Konkretionäre Aufblähung von Gastropodengehäusen. Mitteilungen der Bayerischen Staatssammlung für Paläontologie und historische Geologie 13:3-18.

Galton, P.M. 1990. Basal Sauropodomorpha-Prosauropoda. In The Dinosauria, ed. D.B. Weishampel, P. Dodson, and H. Osmolska, 320-344. Berkeley: University of California Press.

Gerber, J. 1996. Revision der Gattung Vallonia Risso 1826 (Mollusca: Gastropoda: Valloniidae). Schriften zur Malakozoologie 8:1-227.

Gittenberger, E. 1979. On Elona (Pulmonata, Elonidae fam. nov.). Malacologia 18(1/2):139-145.

Gottschick, F., and W. Wenz. 1916. Die Sylvanaschichten von Hohenmemmingen und ihre Fauna. Nachrichtsblatt der deutschen Malakozoologischen Gesellschaft 48(1):17-31. [continued: p. 55-74, 97-113].

Harry, H.W., and B. Hubendick. 1964. The freshwater pulmonate Mollusca of Puerto Rico. Göteborgs Kungl. Vetenskaps Och Vitterhets-Samhalles Handlingar, (6B) 9(5):77.

Harzhauser, M., and H. Binder. 2004. Synopsis of the Late Miocene mollusc fauna of the classical sections Richardhof and Eichkogel in the Vienna Basin. Archiv für Molluskenkunde 133(1/2):109_ 165.

Heissig, K. 1997. Mammal faunas intermediate between the reference faunas of MN 4 and MN 6 from the Upper Freshwater Molasse 
of Bavaria. In Actes du Congres BiochroM'97, Memoires et Travaux de l'Ecole Pratique des Hautes Etudes, eds. Aguilar, J.P., Legendre, S., and Michaux, J., Institut de Montpellier, 21: 537-546.

Heissig, K. 2005. The stratigraphic position of the fossil site Sandelzhausen. In: Rössner, G., ed., Sandelzhausen symposium 2005 - symposium on the Miocene Fossillagerstätte Sandelzhausen (Mainburg, Bavaria, Germany), 13th to 15th September in Mainburg, Program: 36-38.

Herbert, D., and D. Kilburn. 2004. Field guide to the land snails and slugs of eastern South Africa. 336 pp., Pietermaritzburg (Natal Museum).

Hesse, P. 1923. Beiträge zur näheren Kenntnis der Familie Vitrinidae. Archiv für Molluskenkunde 55(1/2):1-25, (3):81-115, (4):129_ 145, Taf. 1-2.

Hubendick, B. 1955. Phylogeny in the Planorbidae. Transactions of the Zoological Society of London 28:453-542.

Hubendick, B. 1961. Studies on Venezuelan Planorbidae. Meddelanden Göteborgs Musei Zoologiska Avdelning 132:1-50.

Jickeli, C.F. 1873. Diagnosen neuer Mollusken meiner Reiseausbeute. I. Landmollusken. Malakozoologische Blätter 20[1872] (2):99_ 108.

Jooss, C.H. 1912. Neue Landschnecken aus dem Obermiocän von Steinheim am Aalbuch in Württemberg. Nachrichtsblatt der deutschen Malakozoologischen Gesellschaft 44(1):30-45.

Jooss, C.H. 1918. Vorläufige Mitteilungen über tertiäre Land- und Süßwasser-Mollusken. Centralblatt für Mineralogie, Geologie und Paläontologie 1918:287-294.

Klein, A. von 1846. Conchylien der Süsswasserkalkformationen Württembergs. Jahreshefte des Vereins für vaterländische $\mathrm{Na}$ turkunde in Württemberg 2(1):60-116.

Kowalke, T. 2005. In The gastropod fauna of Sandelzhausen as a tool for palaeoenvironmental reconstruction, ed. Rössner, G., Sandelzhausen symposium 2005 - symposium on the Miocene Fossillagerstätte Sandelzhausen (Mainburg, Bavaria, Germany), 13th to 15th September in Mainburg, Program: 46.

Ložek, V. 1964. Die Quartärmollusken der Tschechoslowakei. Rozpravy Ústredniho ústavu geologického 31:1-374.

Lueger, J.P. 1981. Die Landschnecken im Pannon und Pont des Wiener Beckens. Denkschriften, Österreichische Akademie der Wissenschaften, Mathematisch-naturwissenschaftliche Klasse 120:124.

Magnin, F. 1993. Quaternary non-marine Mollusca and palaeoclimates in Mediterranean France. Scripta Geologica, Special Issue $2: 275-289$.

Manganelli, G., and F. Giusti. 2000. Drepanostoma helenae, a new helicodontine land snail from the Lower Pliocene of Balze di Caspreno near Siena (central Italy) and a discussion on the status of Protodrepanostoma GERMAIN, 1929 (Gastropoda, Pulmonata: Hygromiidae). Bollettino della Società Paleontologica Italiana 39(3):351-358.

Mensink, H., B. Bahrig, and W. Mergelsberg. 1984. Die Entwicklung der Gastropoden im Miozänen See des Steinheimer Beckens (Süddeutschland). Palaeontographica A 183(1/3):1-63.

Moine, O., D.-D. Rousseau, and P. Antoine. 2005. Terrestrial molluscan records of Weichselian lower to middle pleniglacial climatic changes from the Nussloch loess series (Rhine Valley, Germany): the impact of local factors. Boreas 34(3):363-380.

Moser, M. 2000. Paläobodenbildung und ihr Einfluß auf die Interpretation der Gastropodenfauna von Sandelzhausen (OSM; Bayern). Meeting of the Molasse Group, April 2000, Kempten, Abstracts: 10-11.

Moser, M. 2003. Plateosaurus engelhardti Meyer, 1837 (Dinosauria: Sauropodomorpha) aus dem Feuerletten (Mittelkeuper; Obertrias) von Bayern. Zitteliana (B) 24:3-186.
Moser, M. 2005. Field observations regarding taphonomy, pedogenesis and late diagenesis. - In: Rössner, G., ed., Sandelzhausen Symposium 2005 - Symposium on the Miocene Fossillagerstätte Sandelzhausen (Mainburg, Bavaria, Germany), 13th to 15th September in Mainburg, Program: 52.

Moser, M., G.E. Rössner, U.B Göhlich M. Böhme, Fahlbusch, V. 2009 this volume. The fossillagerstätte Sandelzhausen (Miocene; southern Germany): history of investigation, geology, fauna and age. In Fossil lagerstätte Sandelzhausen (Miocene, southern Germany): Contributions to the fauna, Paläontologische Zeitschrift, eds. Rössner, G.E., and Göhlich, U.B.: 83(1):000-000.

Niederhöfer, H.-J., and G. Falkner. 2004. Taxonomische und stratigraphische Neubewertung der fossilen Molluskenfauna aus der Bären- und Karlshöhle bei Erpfingen (Schwäbische Alb). Laichinger Höhlenfreund 38(2):145-193.

Nordsieck, H. 1986. Das System der tertiären Helicoidea Mittel- und Westeuropas (Gastropoda: Stylommatophora). Heldia 1(4):109120.

Nützel, A., and K. Bandel. 1993. Studies on the side-branch planorbids (Mollusca, Gastropoda) of the Miocene crater lake of Steinheim am Albuch (southern Germany). Scripta Geologica. Special Issue 2:313-357.

Pilsbry, H.A. 1893. Preliminary outline of a new classification of the Helices. Proceedings of the Academy of Natural Sciences of Philadelphia 44(1892):403.

Pilsbry, H. A. 1916-1918. Pupillidae (Gastrocoptinae).-Manual of Conchology, (2) 24 (93): 1-112, pls. 1-13 [1916]; 24 (94): 113176, pls. 14-29 [1917]; 24 (95): 177-256, pls. 30-38 [1917]; 24 (96): 257-380 + i-xii, pls. 39-49 [1918]. Philadelphia, Pa.

Pilsbry, H.A. 1927-1935. Geographic distribution of Pupillidae, Strobilopsidae, Valloniidae and Pleurodiscidae. Manual of Conchology (2), 28:xii + 226 pp.

Remane, A. 1943. Die Bedeutung der Lebensformtypen für die Ökologie. Biologia Generalis 17:164-183.

Retallack, G.J. 2001. Soils of the past an introduction to paleopedology. Second edition. [xii] + 404 pp., Oxford (Blackwell).

Reuss, A.E. 1868. Palaeontologische Beiträge. Zweite Folge. Sitzungsberichte der k. Akademie der Wissenschaften Wien, I. Abtheilung, Mathematisch-Naturwissenschaftliche Classe 57(1): 70-109.

Sandberger, C.L.F. 1870-1875. Die Land- und Süsswasser-Conchylien der Vorwelt.-viii + 1000 pp., Wiesbaden (C. W. Kreidel). [For revised publication dates of parts see Appendix B, this work].

Sandberger, C.L.F. 1872. [Letter to the editor, 16.11.1871]. Neues Jahrbuch für Mineralogie, Geologie und Paläontologie, 18(1):73-76.

Sandberger, C.L.F. 1874. Die Steinheimer Planorbiden. Verhandlungen der Physikalisch-Medicinischen Gesellschaft in Würzburg. Neue Folge 5(4):231-232.

Schlickum, W.R. 1976. Die in der pleistozänen Gemeindekiesgrube von Zwiefaltendorf a d. Donau abgelagerte Molluskenfauna der Silvanaschichten. Archiv für Molluskenkunde 107(1/3):1-31.

Schlickum, W.R., and F. Strauch. 1970. Fossile Arten der Gattung Soosia P. Hesse und Helicigona Risso. Archiv für Molluskenkunde 100(3/4):165-177.

Schmidt, W. 2002. Ablagerungsmilieu, Verwitterung und Paläoböden feinklastischer Sedimente der Oberen Süßwassermolasse Bayerns. Bayerische Akademie der Wissenschaften, mathematischnaturwissenschaftliche Klasse, Abhandlungen, Neue Folge 172:1-247.

Scholz, H., and J.H. Hartman. 2007. Paleoenvironmental reconstruction of the Upper Cretaceous Hell Creek Formation of the Williston Basin, Montana, USA: implications from the quantitative analysis of unionoid bivalve taxonomic diversity and morphologic disparity. Palaios 22(1):24-34. 
Starmühlner, F. 1988. Ergebnisse der Österreichisch-Französischen Hydrobiologischen Mission 1979 nach Guadeloupe, Dominica und Martinique (Kleine Antillen). Teil II: Beiträge zur Kenntnis der Süß- und Brackwassermollusken von Guadeloupe, Dominica und Martinique. Annalen des Naturhistorischen Museums in Wien 90B:221-340.

Thompson, F.G. 1984. Freshwater snails of Florida: A manual for identification. $\mathrm{x}+94$ pp., Gainesville: University of Florida Press.

Truc, G. 1971a. Gastéropodes continentaux néogènes du bassin rhodanien. $\mathrm{V}^{\mathrm{e}}$ Congrès du neogène méditerannéenne, Lyon, 1 , [ed. Anonymous], Documents des Laboratoires de Géologie, Université Lyon, H. S. [unnumbered]:79-129.

Truc, G. 1971b. Heliceae (Gastropoda) du néogène du bassin rhodanien (France). Geobios 4(4):273-327.

Tütken, T., and T. Vennemann. 2009 this volume. Stable isotope ecology of Miocene large mammals from Sandelzhausen, southern Germany. In Fossil lagerstätte Sandelzhausen (Miocene, southern Germany): Contributions to the fauna. Paläontologische Zeitschrift, ed Rössner, G.E., and Göhlich, U.B., 83(1):000-000.

Turgeon, D.D., J.F. Quinn, A.E. Bogan, E.V. Coan, F.G. Hochberg, W.G. Lyons, P.M. Mikkelsen, R.J. Neves, C.F.E. Roper, G. Rosenberg, B. Roth, A. Scheltema, F.G. Thompson, M. Vecchione, J.D. Williams. 1998. Common and scientific names of aquatic invertebrates from the United States and Canada: Molluscs. 2nd. edn. American Fisheries Society Special Publication 26:ix+526pp.

Wenz, W. 1915. Die fossilen Arten der Gattung Strobilops Pilsbry und ihre Beziehungen zu den lebenden. Neues Jahrbuch für Mineralogie, Geologie und Paläontologie 1915 II(1):63-88.
Wenz, W. 1920. Über das Vorkommen von Cepaea eversa larteti (Boissy) in den schwäbischen Silvanaschichten und ihre Bedeutung für deren Gliederung. Senckenbergiana II 6:151-158.

Wenz, W. 1924. Die Flammenmergel der Silvanaschichten und ihre Fauna. Jahresberichte und Mitteilungen des oberrheinischen geologischen Vereins, Neue Folge 12:181-186.

Wenz, W. 1923-1930. Gastropoda extramarina tertiaria. Fossilium Catalogus, I: Animalia: 3387 pp., Berlin (W. Junk). [Pars 17:1-352 (20.3.1923); 18:353-736 (27.4.1923); 20:737-1068 (5.6.1923); 21:1069-1420 (2.8.1923); 22:1421-1734 (9.9.1923); 23:17351862 (20.11.1923); 32:1863-2230 (26.2.1926); 38:2231-2502 (28.7.1928); 40:2503-2886 (4.2.1929); 43:2887-3014 (8.7.1929); 46:3015-3387 (10.4.1930)].

Wenz, W. 1938-1944. Gastropoda. Teil I: Allgemeiner Teil und Prosobranchier (Amphigastropoda und Streptoneura). Handbuch der Palaeozoologie 6(1):xii+1639.

Willmann, R. 1988. Probleme bei biostratigraphischen Koordinierungen mit Hilfe neogener Süßwassergastropoden. Meyniana 40:155-173.

Witt, W. 1998. Die miozäne Fossil-Lagerstätte Sandelzhausen. 14. Ostracoden. Mitteilungen der Bayerischen Staatssammlung für Paläontologie und historische Geologie 38:135-165.

Woodward, B.B. 1906. On the dates of publiaction of C. L. F. von Sandberger's 'Die Land- und Süsswasser-Conchylien der Vorwelt,' 4to, Wiesbaden (C. W. Kreidel), 1870-75. Proceedings of the Malacological Society of London 7(1):3-4.

Zilch, A. 1959-1960. Gastropoda, Teil II: Euthyneura. In Handbuch der Paläozoologie ed. Schindewolf, O.H.,6(2), Lief. 1-2:1-400 [1959], Lief. 3-4: XII + 401-834 [1960], Berlin (Borntraeger). 